\title{
Reducing Government Debt in the Presence of Inequality*
}

\author{
Sigrid Röhrs ${ }^{\dagger}$ and Christoph Winter ${ }^{\ddagger}$
}

February 4, 2014

\begin{abstract}
What are the welfare consequences of debt reduction policies? In this paper, we answer this question with the help of an incomplete markets economy with production in which households are subject to uninsurable income shocks. We focus on policies that raise revenues from taxing income. We make three contributions. First, we show that quantitatively sizable welfare gains can be reaped by reducing debt, at least in the long-run. Second, we find that, for some policies, the short-run losses that occur during the transition more than outweigh the long-run gains. And third, we show that both short-run and long-run welfare effects of government debt depend on the income composition of the consumption-poor. In our calibration, we thus target the skewed wealth and the earnings distribution of the US economy. Our results have important implications for the design of debt reduction strategies. Policies that imply more redistribution will find more political support, as they compensate the consumption-poor, who suffer the most during the transition.
\end{abstract}

Key words: Government Debt, Borrowing Limits, Incomplete Markets, Crowding Out

JEL classification: E2, H6, D52

\footnotetext{
*Acknowledgements: We would like to thank Alexander Bick, Timo Boppart, Nicola Fuchs-Schündeln, Wouter den Haan, John Hassler, Marcus Hagedorn, Kenneth Judd, Leo Kaas, Timothy Kehoe, Nobuhiro Kiyotaki, Felix Kübler, Alex Michaelides, Dirk Niepelt, Karl Schmedders, Kjetil Storesletten, Iván Werning as well as participants of various seminars and especially Fabrizio Zilibotti for many useful comments. Röhrs would like to thank the University of Zurich for financial support (Forschungskredit Nr. 53210601). Winter gratefully acknowledges financial support from the European Research Council (ERC Advanced Grant IPCDP-229883) and the National Centre of Competence in Research "Financial Valuation and Risk Management" (NCCR FINRISK). All remaining errors are our own. Parts of this project were previously circulated under the title Wealth Inequality and the Optimal Level of Government Debt.

$\dagger^{\dagger}$ Goethe University Frankfurt, Chair of Macroeconomics and Development, Office HOF 3.42, Grüneburgplatz 1, D60323 Frankfurt am Main (Germany), +49 (069) 798337 95, Sigrid.Roehrs@hof.uni-frankfurt.de

${ }^{\ddagger}$ University of Zurich, Department of Economics, Office MUB-G405, Mühlebachstrasse 86, 8008 Zurich (Switzerland), +41 (044) 63452 66, christoph.winter@econ.uzh.ch
} 


\section{Introduction}

Many countries - including the United States - have experienced a dramatic surge in their public debt levels in the aftermath of the 2007-08 financial crisis. Drastic measures, including tax increases, need to be applied to bring government debt back to its pre-crisis level. ${ }^{1}$ However, history has shown that austerity measures are very unpopular and that their political implementation is difficult. As suggested by Reinhart and Rogoff (2009), historically, many countries have chosen to default on their sovereign debt even at moderate debt/GDP ratios in order to avoid painful austerity policies.

In this paper, we analyze the welfare consequences of government debt reductions by means of tax changes. In particular, we are interested in identifying the subgroups of the population that suffer the most during fiscal consolidation. We also discuss ways how tax adjustments could be designed such that debt reduction policies are supported by a majority of the population. In our environment, income and wealth are highly unequally distributed, as they are in the US. In an unequal society, the impact of fiscal adjustment on the welfare of a specific household depends on, among other things, the income composition of this household and whether this household is borrowing constrained. We find that the majority of households suffers from reducing government debt in the short-run, but gains in the longrun. For many subgroups, the short-run losses outweigh the long-run gains. This explains why it is so difficult to find political support for austerity policies, despite the fact that, according to our analysis, long-run gains are substantial.

Key for our results is the fact that in our environment, the existence of borrowing limits prevents households from smoothing their consumption efficiently over time. Poor households would like to take out more loans today when taxes are increased and government debt is reduced, because they expect more consumption in the future, when debt is low. However, binding borrowing constraints prevent them from doing so. We show that the government can partly alleviate the impact of borrowing constraints by making the tax code slightly more redistributive. Hence, one possible recipe in order to get political support is to make the tax system more progressive.

We conduct our analysis with the help of an incomplete markets framework in the tradition of Aiyagari (1994). Households are subject to idiosyncratic productivity shocks. These shocks are uninsurable because insurance markets are absent. Households can self-insure against adverse shocks by accumulating precautionary savings or by borrowing. In our framework, borrowing is limited. This restricts the ability of households to self-insure.

This framework is ideal for our purposes for two reasons. First, government debt plays a non-trivial role if markets are incomplete or if borrowing is restricted. This was shown in the seminal papers of Woodford (1990) and Aiyagari and McGrattan (1998). In Woodford (1990), government debt relaxes binding borrowing constraints. Aiyagari and McGrattan (1998) argue that government debt helps to 'complete' markets because it facilitates precautionary saving. Issuing government debt might thus be an effective way to improve risk-sharing and aggregate welfare (Flodén, 2001, Shin, 2006, Albanesi, 2008).

Second, the fact that markets are incomplete and risk-sharing is limited generates a non-trivial

\footnotetext{
${ }^{1}$ See Chen and Imrohoroglu (2012) for an overview over several proposals to reduce government debt that are discussed for the US. They conclude that, even if some of these proposal were implemented, the government debt (held by the public)/GDP ratio is likely to increase to 100 percent during the next 30 years.
} 
distribution of assets and consumption. We show that the degree of inequality implied by the model is crucial for assessing the welfare effects of government debt. In order to generate a distribution of earnings and assets that resembles the skewed distributions of earnings and wealth in the US economy, we follow Castañeda, Díaz-Giménez, and Ríos-Rull (2003) in our calibration of the stochastic process that governs the evolution of idiosyncratic earning shocks. Moreover, the fact that our model generates the skewed wealth distribution observable in the US allows us to adequately pin down the impact of different debt reduction strategies on several subgroups of the population. It also allows us to precisely compute the political support that various austerity policies could achieve.

Our results are as follows. If we only focus on the long-run effects of lower debt/GDP ratios, we find that reducing government debt raises aggregate welfare. In order to understand this result, it is important to consider the impact of borrowing constraints in greater detail. If borrowing constraints are binding, lowering government debt crowds in private capital. This is because households that face binding borrowing constraints will not decrease their savings one-to-one in response to a decrease in debt, and the Ricardian Equivalence breaks down. This implies that the demand for private bonds will not meet the supply of private bonds issued by the firm. We say that public debt crowds in the capital stock, and therefore also production and output. As a result, the equilibrium interest rate that clears the private bond market will decrease, and the marginal product of labor will increase. Moreover, if taxation is distortionary instead of lump-sum, the positive effect of government debt on capital and output is even stronger, since less government debt means lower taxes and therefore reduces the inefficiencies caused by distortionary taxes.

In a world in which markets are incomplete and in which there is heterogeneity among households, the changes in the interest rate and the wage rate resulting from crowding in and lower distortionary taxation affect aggregate welfare via two additional channels. First, a lower interest rate makes self-insurance more difficult for private households, since saving yields a lower return (Aiyagari and McGrattan, 1998). Put differently, the price of the riskless production factor (capital) decreases, while the price of the risky factor (labor) increases. Lower debt/GDP ratios thus have a negative effect on aggregate welfare, since self-insurance becomes more difficult. Changes in market clearing prices that affect welfare when markets are incomplete are also key in Gottardi, Kajii, and Nakajima (2010) and Davila et al. (2011). These papers analyze whether the laissez-faire outcome is constrained efficient if markets are incomplete. ${ }^{2}$ Second, government debt also affects the distribution of consumption via the composition of income, because households that receive capital income lose and households that mainly rely on labor income win. This income composition channel might help to partly outweigh the negative effect of the insurance channel on aggregate welfare, since the households that profit the most from the increase in wages are the consumption-poor.

We show that our finding that reducing government debt is beneficial for aggregate welfare in the long-run hinges on the fact that wealth and income in the United States are very unequally distributed across the population. Because households that are consumption-poor also hold no wealth or are even in debt, the negative insurance effect of government debt has only a small impact on aggregate welfare. As a result, in our calibration, the positive welfare effects more than offset the insurance effect. Instead,

\footnotetext{
${ }^{2}$ Gottardi, Kajii, and Nakajima (2010) and Davila et al. (2011) find that, depending on the structure of uncertainty, the constrained efficiency requires a higher level of capital compared to the competitive equilibrium outcome when markets are incomplete.
} 
Aiyagari and McGrattan (1998) and Flodén (2001) conclude that the opposing effects almost cancel out, leading to only weak overall welfare effects of government debt.

Thus, by explicitly targeting the high wealth and earnings inequality observed in the US in our calibration procedure, our project also contributes to the literature that analyzes the welfare effects of government debt following Castañeda, Díaz-Giménez, and Ríos-Rull (2003). ${ }^{3}$ We show that taking into account the high degree of inequality in the US may lead to very different conclusions about the welfare effects of government debt.

We also analyze the transitional (short-run) welfare effects of government debt reductions that occur between stationary equilibria. We focus on policies, where changes in debt/GDP ratios are financed by either adjustments in the (proportional) tax rate on labor income or by changes in the (proportional) tax rate on capital income. The welfare costs of a public debt reduction using these policies are high. In fact, in most of the experiments that we consider, the costs of reducing public debt easily outweigh the welfare gains associated with the new stationary equilibrium, in which the debt/GDP ratio is lower.

In order to understand the determinants of the large welfare losses that arise if government debt is reduced, it is again important to consider the role of inequality. Reducing government debt means that taxes need to be increased. This primarily affects the wealth-poor, independently of whether labor income taxes or capital income taxes are raised. In order to see this, consider first an increase in labor income taxes. Taxing labor income has adverse effects on the wealth-poor, which rely heavily on labor income to finance their consumption expenditures. If instead capital income is taxed, the saving decisions are distorted, which reduces the aggregate capital stock and therefore also equilibrium output. As a result, the equilibrium wage rate is lower as well, which again hurts those who need to rely on labor income. ${ }^{4}$ Interestingly, because of inequality, short-run and long-run welfare effects of public debt have the opposite sign. This mechanism also underlines the importance of studying both long-run and short-run effects of government debt.

Given the high welfare costs of debt reductions, it is thus not surprising that only few policies would enjoy enough support to be implemented by a majority vote. Our findings thus provide an explanation for the fact that fiscal consolidation leads to social unrest, as documented by Ponticelli and Voth (2011). In earlier work, Alesina and Perotti (1996) have established a link between inequality and social unrest. In a related recent contribution, D'Erasmo and Mendoza (2012) study the link between domestic inequality and the likelihood to default on domestic debt in an incomplete markets model similar to ours. They find that inequality increases the probability to default.

We find that a government can gain support for a reform if it increases the progressivity of the tax system. In this case, there is more redistribution from the rich to the poor during the process during which government debt is reduced. This redistribution helps consumption-poor households that are at the borrowing constraint to smooth their consumption profile over time. Put differently, lowering taxes for poor households during the periods in which government debt is decreased enables them to bring

\footnotetext{
${ }^{3}$ The technique by Castañeda, Díaz-Giménez, and Ríos-Rull (2003) is widely applied in the literature, see e.g. Davila et al. (2011).

${ }^{4}$ If the implementation of the capital income tax is unanticipated, there are no saving distortions in the initial period. This somehow mitigates the welfare costs of debt reductions, but does not avoid them. This is due to the fact that the capital stock may still shrink because the capital income tax is larger than 100 percent. In this case, wages still fall initially, and because there are borrowing constraints, those without assets cannot respond by increasing their borrowing in order to smooth out their consumption.
} 
forward part of their long-run consumption gains. Financing lower government debt levels by means of a more progressive tax system dramatically increases the popularity of these measures among the population. Interestingly, our results relate to the current policy debate, taking place in the US and in many other countries, including France and Germany, where proposals to make the tax system more progressive in order to raise tax revenues are discussed.

Apart from the aforementioned work by Aiyagari and McGrattan (1998) and Flodén (2001), our project is also related to other papers that study the impact of fiscal policy in quantitative models with incomplete markets. Domeij and Heathcote (2004) and Conesa, Kitao, and Krueger (2009) study the welfare effects of abolishing capital taxation. Ludwig and Krüger (2013) compute the optimal tax progressivity and education subsidies in a model with endogenous human capital formation. The optimal degree of tax progressivity is also the focus of Bakis, Kaymak, and Poschke (2012). Heathcote (2005) analyses the impact of tax changes on aggregate consumption. Gomes, Michaelides, and Polkovnichenko (2013) quantify the crowding out effect on the capital stock of a 10 percent increase in government debt in an incomplete market economy with aggregate risk. Angeletos and Panousi (2009) and Challe and Ragot (2010) study the effects of changes in government expenditures in incomplete market models. Oh and Reis (2012) study the impact of government transfers. Gomes, Michaelides, and Polkovnichenko (2012) aim at quantifying the fiscal costs of the recent financial crisis in US. Desbonnet and Weitzenblum (2011) and Azzimonti, de Francisco, and Quadrini (2012) also exploit the fact that government debt facilitates self-insurance, as we do in our work. The explicit characterization of the welfare consequences of debt reductions in the long- and short-run is not the main objective of any of the aforementioned papers.

The remainder of the paper is structured as follows. We present the baseline model in the next section. In section 3 we discuss the calibration of the model. Section 4 shows the quantitative results. Section 5 concludes.

\section{The Baseline Model}

The economy we consider is a neoclassical growth model with incomplete markets where households face uninsurable income shocks, as in Aiyagari (1994). The economy consists of three sectors: households, firms and a government. In the following, we describe the three sectors in greater detail. We start by describing the bonds that households in our economy use to accumulate savings.

\subsection{Supply and Demand for Bonds}

Households self-insure against income fluctuations by saving in one-period risk-free bonds. Bonds are issued by firms and the government, as in Aiyagari and McGrattan (1998) and Flodén (2001). Bonds issued by firms are claims to physical capital. We abstract from aggregate risk, which implies that claims to physical capital and government bonds are perfect substitutes and thus yield the same return, $r_{t} .{ }^{5}$ Different from Aiyagari and McGrattan (1998) and Flodén (2001), we also allow households to borrow

\footnotetext{
${ }^{5}$ In Gomes, Michaelides, and Polkovnichenko $(2012,2013)$, government bonds and private capital are imperfect substitutes due to aggregate uncertainty.
} 
up to a certain limit. We view this as an important modification, given that the fraction of households that actually borrow in the data is substantial. ${ }^{6}$

\subsection{Household Sector}

The economy is populated by a continuum of ex-ante identical, infinitely lived households with total mass of one. Households maximize their expected utility by making a series of consumption, $c_{t}$, labor, $l_{t}$, and savings, $a_{t+1}$, choices subject to a budget constraint and a borrowing limit on assets. In period $t=0$, before any uncertainty has realized, their expected utility is given by

$$
U\left(\left\{c_{t}, 1-l_{t}\right\}_{t=1,2, \ldots}\right)=E_{0} \sum_{t=0}^{\infty} \beta^{t} u\left(c_{t}, 1-l_{t}\right)
$$

where $\beta$ is the subjective discount factor. The per-period utility function, $u($.$) , is assumed to be strictly$ increasing, strictly concave and continuously differentiable. Additionally the first derivative is assumed to satisfy the following limiting (Inada) conditions:

$$
\begin{aligned}
\lim _{c \rightarrow 0} u_{c}(c, 1-l) & =\infty, \lim _{c \rightarrow \infty} u_{c}(c, 1-l)=0 \\
\lim _{l \rightarrow 0} u_{1-l}(c, 1-l) & =\infty
\end{aligned}
$$

Household productivity is subject to a shock, $\epsilon$, that follows a Markov process with transition matrix $\pi\left(\epsilon^{\prime} \mid \epsilon\right)$.

A household faces the following per-period budget constraint:

$$
c_{t}+a_{t+1}=y_{t}+a_{t}
$$

where $a_{t+1}$ denotes the bond holdings of a household. $y_{t}$ is the household's (after-tax) income. Notice that $a_{t+1}$ may also be negative, in which case the household borrows. Borrowing is restricted:

$$
a_{t+1} \geq \underline{a}
$$

The fact that we impose an exogenous borrowing constraint is important. With a natural borrowing constraint and lump sum taxes government debt is neutral (Ricardian equivalence holds).

The tax system in our economy consists of affine taxes, where $\tau_{l, t}$ and $\tau_{a, t}$ denote a proportional tax on labor income and financial income, respectively. Lump-sum subsidies $t r_{t}$ can be used to redistribute income. Figure 1 in Golosov and Sargent (2012) suggests that affine taxes are a very good approximation to the US tax code. In our benchmark model, we assume that the transfers stay constant over time, i.e. $t r_{t}=t r$. We assume that only non-negative financial income is taxed or in other words, there are no proportional subsidies in the face of financial losses. More precisely, we define the tax on financial income $\tau_{a, t}$, as follows:

$$
\tau_{a, t}(a)=\left\{\begin{array}{c}
\bar{\tau}_{a, t} \text { if } a \geq 0 \\
0 \text { if } a<0
\end{array}\right.
$$

The after-tax interest rate is therefore given by $\bar{r}_{t}=\left(1-\tau_{a, t}(a)\right) r_{t}$. The after-tax wage rate is given by $\bar{w}_{t}=\left(1-\tau_{l, t}\right) w_{t}$ where $w_{t}$ is the price of labor in the economy. After-tax income is thus given by:

$$
y_{t}=\bar{w}_{t} \epsilon l_{t}+\bar{r}_{t} a+t r_{t}
$$

\footnotetext{
${ }^{6}$ Borrowing by households can be interpreted as bonds that are issued to other households ('IOUs') or to the government.
} 
The optimization problem of a household is given by the following functional equation:

$$
\begin{aligned}
W_{t}(a, \epsilon) & =\max _{c, l, a^{\prime}}\left\{u(c, 1-l)+\beta \sum_{\epsilon^{\prime}} \pi\left(\epsilon^{\prime} \mid \epsilon\right) W_{t+1}\left(a^{\prime}, \epsilon^{\prime}\right)\right\} \\
\text { s.t. } c+a^{\prime} & =\bar{w}_{t} \epsilon l+\left(1+\bar{r}_{t}\right) a+t r_{t} \\
a^{\prime} \geq & \underline{a}
\end{aligned}
$$

The household's problem is time-dependent because we do not only study steady-states but also transitions between steady-states. ${ }^{7}$

\section{$2.3 \quad$ Firm Sector}

We assume that the aggregate production technology which is operated by a representative firm to produce output, $Y_{t}$, using aggregate capital, $K_{t}$, and aggregate labor, $N_{t}$, as inputs is given as follows:

$$
Y_{t}=F\left(K_{t}, X_{t} N_{t}\right)
$$

where $X_{t}$ denotes exogenous labor-augmenting technological progress. This technology is assumed to grow exogenously at a constant rate $X_{t+1}=(1+g) X_{t}$. For simplicity we normalize initial technology to $X_{0}=1$, such that:

$$
X_{t}=(1+g)^{t}
$$

The presence of technological progress implies that households, on average, become richer over time. Technological progress thus increases the propensity of households to borrow.

The aggregate production function, $F$, is assumed to have the standard properties, in particular constant returns to scale. This ensures that in competitive equilibrium, the number of firms is indeterminate and we can assume the existence of a representative firm, without loss of generality.

\subsection{Government Sector}

The government has to finance a time-invariant amount of government spending, $G$, and the total transfers to households, $T r_{t}$, by issuing new government bonds, $B_{t+1}$, and levying taxes on positive asset and labor income. Furthermore, the government services its debt, $B_{t}$, and makes interest payments, $r_{t} B_{t}$. The government budget constraint is thus given by:

$$
G+r_{t} B_{t}+T r_{t}=B_{t+1}-B_{t}+\tau_{l} w_{t} N_{t}+\bar{\tau}_{a} r_{t} \widehat{A}_{t}
$$

where $\widehat{A}_{t} \geq A_{t}$ is the tax base for the asset income tax. As explained above taxes are only levied on positive financial income (no proportional transfers from the government for indebted people) and thus the tax base is defined as:

$$
\widehat{A_{t}}=\int_{a \geq 0} a d \theta_{t}(\epsilon, a)
$$

\footnotetext{
${ }^{7}$ Notice that as long we focus on transition between steady-states, the dynamic programming problem of the household falls into the class of stationary dynamic programming problems for which the principle of optimality is satisfied. We numerically show that our economy converges to a new steady-state.
} 
where $\theta_{t}(\epsilon, a)$ denotes the distribution of households over income and asset states. Aggregate transfers have to equal the sum of all individual transfers:

$$
\int t r_{t} d \theta_{t}(\epsilon, a)=T r_{t}
$$

\subsection{Competitive Equilibrium}

Using the characterization of the three sectors we can now define the competitive equilibrium.

Definition 1. Competitive Equilibrium: Given a transition matrix $\pi$, a government policy $\left\{B_{t}, \tau_{a, t}(a), \tau_{l, t}, G\right\}_{t=0}^{\infty}$, and an initial distribution of the idiosyncratic productivity shocks and of the asset holdings $\theta_{0}(\epsilon, a)$ a recursive competitive equilibrium is defined by a law of motion $\Gamma$, factor prices $\left\{r_{t}, w_{t}\right\}_{t=0}^{\infty}$, a sequence of value functions $\left\{W_{t}\right\}_{t=0}^{\infty}$ and a sequence of policy functions $\left\{c_{t}, l_{t}, a_{t}^{\prime}\right\}_{t=0}^{\infty}$ such that

1. Households solve the utility maximization problem as defined in equation (1).

2. Competitive firms maximize profits, such that factor prices are given by

$$
\begin{aligned}
w_{t} & =F_{L}\left(K_{t}, X_{t} N_{t}\right) \\
r_{t} & =F_{K}\left(K_{t}, X_{t} N_{t}\right)-\delta
\end{aligned}
$$

3. The government budget constraint as defined in equation (2) holds.

4. Factor and goods markets have to clear:

- Labor market:

$$
N_{t}=\int \epsilon l_{t} d \theta_{t}(\epsilon, a)
$$

- Asset market:

$$
A_{t+1}=\int a_{t}^{\prime} d \theta_{t}(\epsilon, a)=K_{t+1}+B_{t+1}
$$

- Goods market:

$$
\int c_{t} d \theta_{t}(\epsilon, a)+G+I_{t}=F\left(K_{t}, X_{t} N_{t}\right)
$$

where investment, $I_{t}$ is given by:

$$
I_{t} \equiv K_{t+1}-(1-\delta) K_{t}
$$

5. Rational expectations of households about the law of motion of the distribution of shocks and asset holdings, $\Gamma$ reflect the true law of motion, as given by

$$
\theta_{t+1}(a, \epsilon)=\Gamma\left[\theta_{t}(a, \epsilon)\right]
$$

where $\theta_{t}(a, \epsilon)$ denotes the joint distribution of asset holdings and productivity shocks. 


\subsection{Welfare Measure}

In order to be able to compare the welfare effects of different government policies, we have to define a welfare criterion. Following the previous literature as for example, Aiyagari and McGrattan (1998) and Flodén (2001), we compute the aggregate value function:

$$
\Omega_{t}=\int W_{t}(a, \epsilon) d \theta_{t}(a, \epsilon)
$$

This criterion can either be interpreted as (1) a Utilitarian social welfare function where every individual has the same weight for the planner, (2) a steady-state ex ante welfare of an average consumer before realizing income shocks and initial asset holdings or (3) the probability limit of the utility of an infinitely lived dynasty where households utilities are altruistically linked to each other.

In order to facilitate the interpretation, we compute the average welfare change in consumption equivalent units, i.e. the consumption that needs to be given to each household in order to make households indifferent on average between two specific policies. ${ }^{8}$ More details are provided in the Appendix.

\section{Calibration}

We calibrate our model such that it is consistent with long run features of the US economy. The resulting allocation serves as a benchmark for our welfare calculations.

The parameter values that result from our calibration procedure are shown in Table 1. Parameter values that are adopted from the existing literature are given in Table 2. In the following, we discuss the rationale behind our parameter choices in greater detail.

\subsection{Utility Function and Production Technology}

We assume that preferences can be represented by a constant relative risk aversion utility function:

$$
u(c, 1-l)=\frac{\left(c^{\eta}(1-l)^{1-\eta}\right)^{1-\mu}}{1-\mu}
$$

$\mu$ determines the curvature of the utility function. We set $\mu$ to 2 . This implies a coefficient of risk aversion of $1-\mu+\eta \mu=1.3$, which is well in the range (between 1 and 3) commonly chosen in the literature. $\eta$ denotes the share of consumption in the utility function. We calibrate $\eta$ such that the average share of time worked is 0.3 . This results in $\eta=0.31$. This choice implies an aggregate Frisch elasticity of $1.3 .^{9}$ This is broadly in line with the outcome of other macro models in which the Frisch elasticity of the overall population is considered, but an order of magnitude larger than the Frisch elasticity estimated using micro data from prime age workers. ${ }^{10}$

\footnotetext{
${ }^{8}$ More precisely, this measure provides the percentage increase in benchmark consumption at every date and state (with leisure at every date and state held fixed at benchmark values) that leads to the same welfare (under the benchmark policy) as under the new policy.

${ }^{9}$ For our choice of the utility function, the Frisch elasticity is given by $(1-\mu+\eta \mu) / \mu \cdot(T-\bar{l}) / \bar{l}$, where $T$ denotes the time endowment (normalized to 1 in our case) and $\bar{l}$ denotes the fraction of time spend at work, in our case 0.3.

${ }^{10}$ The debate on whether micro and macro elasticities are consistent is ongoing. See Keane and Rogerson (2011) for a summary.
} 
We assume that the aggregate technology is given by a Cobb-Douglas production function:

$$
F(K, X N)=K^{\alpha}(X N)^{1-\alpha}
$$

Initial technology is normalized to $X_{0}=1$, such that $X_{t}=(1+g)^{t}$. We set $g=0.02$, which implies that our economy grows at a rate of 2 percent per year. The parameter $\alpha$, which denotes the share of capital in total production, is set to 0.3. This implies a labor share of 0.7. The discount factor $\beta$ is chosen such that the model reproduces a wealth-output ratio of 3.1 (cf. Cooley and Prescott (1995) or Ábrahám and Cárceles-Poveda (2010)). The resulting $\beta$ is equal to 0.96. The annual depreciation rate $\delta$ is set to 7 percent, which is a common value in the literature (see e.g. Trabandt and Uhlig (2009)).

Table 1: Calibrated Parameter Values

\begin{tabular}{lrlrr}
\hline \hline \multicolumn{1}{c}{ Parameter } & Value & \multicolumn{1}{c}{ Target } & Data & Model \\
\hline & & & & \\
Discount factor, $\beta$ & 0.96 & Capital to output ratio & 3.1 & 3.1 \\
Weight of consumpt. in the util. funct., $\eta$ & 0.31 & Average labor supply & 0.3 & 0.3 \\
Borrowing constraint $\underline{a}$ & -0.3 & \% of HH with no assets or debt & 0.24 & 0.25 \\
Gov. spending, $G$ & 0.15 & gov. budget constraint clearing & \multicolumn{1}{c}{-} & - \\
\hline \hline
\end{tabular}

\subsection{Taxes and Government Debt}

Following Trabandt and Uhlig (2009), we set the labor income tax rate, $\tau_{l}$, and capital income tax rate, $\tau_{k}$, to 0.28 and 0.36 , respectively. Similar values are also reported by Mendoza, Razin, and Tesar (1994). Lump-sum transfers $t r_{t}$ are set to 0.083, in accordance with Trabandt and Uhlig (2009). Following Aiyagari and McGrattan (1998), we use a debt/GDP ratio of 0.67. Aiyagari and McGrattan (1998) calculate this figure as the average of the sum of US federal and state debt divided by gross domestic product over the postwar period.

Finally, government spending $G$ is set such that the government's budget constraint clears, given all other parameters.

Table 2: Parameters Set Exogenously

\begin{tabular}{lr}
\hline \hline \multicolumn{1}{c}{ Parameter } & Value \\
\hline Capital's share, $\alpha$ & 0.3 \\
Growth rate, $g$ & 0.02 \\
Debt to GDP ratio, $b$ & 0.670 \\
Labor tax, $\tau^{l}$ & 0.28 \\
Capital tax, $\tau^{k}$ & 0.36 \\
Transfers, $t r$ & 0.083 \\
Curvature $\mu$ & 2 \\
\hline \hline
\end{tabular}




\subsection{Income Process}

We calibrate the vector of income states, $s$, and the transition matrix, $\Pi$, such that the distribution of earnings and net worth generated by the model are consistent with the data. Disciplining the model such that it is consistent with the skewed distribution of earnings and wealth observable in the US economy is key for assessing the welfare-maximizing level of government debt. In particular, we are interested in the share of (consumption-) poor households in the economy, who matter more in our Utilitarian welfare criterion, given the concavity of the utility function. In addition, matching inequality is also important in order to determine the factor income composition of the poor, which in turn determines whether poor households gain or lose from changes in government debt.

We compute the distribution of earnings and net financial assets from the 2007 Survey of Consumer Finances (SCF) (see Table 3 and 4). We define net financial assets as net worth excluding housing and other durable goods, following Ábrahám and Cárceles-Poveda (2010). Earnings are defined as labor earnings (wages and salaries) plus a fraction of business income before taxes, excluding government transfers. ${ }^{11}$ This definition is close to the concept of earnings that is implied by our model as well.

Table 3: Distributional Properties at Benchmark Stationary Economy

\begin{tabular}{|c|c|c|c|c|c|c|}
\hline & Q1 & $\mathrm{Q} 2$ & Q3 & Q4 & Q5 & Gin \\
\hline \multicolumn{7}{|c|}{ Net financial assets } \\
\hline Data & $-1.60 \%$ & $0.10 \%$ & $1.64 \%$ & $8.29 \%$ & $91.57 \%$ & 0.90 \\
\hline Benchmark Calibration & $-1.57 \%$ & $0.88 \%$ & $3.92 \%$ & $7.23 \%$ & $89.54 \%$ & 0.83 \\
\hline \multicolumn{7}{|c|}{ Earnings } \\
\hline Data & $-0.40 \%$ & $3.19 \%$ & $12.49 \%$ & $23.33 \%$ & $61.39 \%$ & 0.62 \\
\hline Benchmark Calibration & $0.00 \%$ & $2.38 \%$ & $12.58 \%$ & $22.73 \%$ & $62.31 \%$ & 0.65 \\
\hline
\end{tabular}

Remarks: Quintiles (Q1-Q5) denote net financial assets (resp. earnings) of a group in percent of total net financial assets (resp. earnings). The entries in 'data' are computed from the 2007 SCF. See main text for precise definitions. Notice that earnings can be negative due to the fact that labor earnings also contain part of the gains (or losses) of small enterprises.

Table 3 and 4 show that both earnings and net financial assets are very unequally distributed in the data. The richest 20 percent of the population hold more than 90 percent of all financial assets, net of debt. The distribution of earnings is less skewed. Households in the top quintile earn around 60 percent of the total earnings.

It is well known that for a standard parameterization of the earnings process, incomplete markets models in the tradition of Aiyagari (1994) generate too little inequality compared to the data (see e.g. Quadrini and Ríos-Rull (1997)). We follow Castañeda, Díaz-Giménez, and Ríos-Rull (2003) and calibrate the vector of income states $s$ and the transition matrix $\Pi$ to match the Lorenz curves of US

\footnotetext{
${ }^{11}$ Unfortunately, it is not declared exactly in the SCF how much of the business income is actually labor and how much is capital income. We take business income from sole proprietorship or a farm to be labor earnings, whereas we define business income from other businesses or investments, net rent, trusts, or royalties as capital income.
} 
Table 4: Upper Percentiles of Wealth Distribution at Benchmark

\begin{tabular}{|c|c|c|c|}
\hline & upper $10 \%$ & upper $5 \%$ & upper $1 \%$ \\
\hline \multicolumn{4}{|c|}{ Net financial assets } \\
\hline Data & $79.64 \%$ & $66.83 \%$ & $39.09 \%$ \\
\hline Benchmark Calibration & $70.58 \%$ & $47.03 \%$ & $13.53 \%$ \\
\hline
\end{tabular}

Remarks: The table shows the percent of net financial assets held by the wealthiest $10 \%$ (upper 10\%), $5 \%$ (upper $5 \%$ ) and $1 \%$ (upper 1\%).

earnings and wealth as found in our analysis of the 2007 SCF. In the model, wealth inequality (and consumption inequality) are the result of households' optimal decisions with respect to consumption and saving. Household use assets in order to smooth consumption over time and in order to save against uninsurable income shocks. Households' decision making in turn depends on preference parameters and the specification of the earnings process. In our calibration, we modify the uninsurable income shocks such that the equilibrium asset allocation resembles the observable wealth inequality in the US ${ }^{12}$

Tables 3 and 4 show that our model tracks the observable wealth and earnings distribution very closely, with the exception of the top decile of the wealth distribution. Here, our earnings process generates less inequality than the data, but much more than a standard $\mathrm{AR}(1)$ process. We find the following vector of income states:

$$
s=\{0.055,0.551,1.195,7.351\}
$$

It should be noted that the highest income state is more than 130 times as high as the lowest income state. Furthermore, we get the following transition matrix for the income states:

$$
\Pi=\left[\begin{array}{llll}
0.940 & 0.040 & 0.020 & 0.000 \\
0.034 & 0.816 & 0.150 & 0.000 \\
0.001 & 0.080 & 0.908 & 0.012 \\
0.100 & 0.015 & 0.060 & 0.825
\end{array}\right]
$$

As can be seen from the transition matrix, there is a 10 percent probability of moving from the highest income state today to the lowest income state tomorrow. This generates a strong saving motive for income-rich households, leading to the high degree of wealth inequality that we also observe in the data. The same mechanism is also present in the transition matrix found by Castañeda, Díaz-Giménez, and Ríos-Rull (2003).

\subsection{Borrowing Limit}

We calibrate the ad-hoc borrowing limit to match the percentage of households with negative or zero financial assets in the 2007 SCF (24 percent). We find a borrowing limit of $\underline{a}=-0.3$.

\footnotetext{
${ }^{12}$ An alternative approach, which is due to Krusell and Smith (1998), would be to introduce preference heterogeneity. Krusell and Smith (1998) assume that some households are more patient than others, and thus also accumulate more savings.
} 


\section{Results}

We are now ready to compute the welfare effects of reductions in government debt. We distinguish between short-term and long-term effects. We proceed in two steps. First, we analyze the welfare consequences of government debt reductions in the long-run. This is done by comparing stationary equilibria that are characterized by different debt/GDP ratios, keeping all other parameters constant. In order to keep the budget of the government balanced, we also adjust either the labor tax rate or the capital tax rate. We find that in the long-run, debt reductions are associated with welfare gains. In a second step, we also incorporate the welfare effects that occur over the transition between a high-debt stationary equilibrium to a low-debt equilibrium. We find that the costs of debt reductions occurring over the transition can be substantial, depending on the policy. The short-run costs of debt reductions can easily outweigh the long-run gains.

\subsection{Effects of Public Debt in the Stationary Equilibrium}

In Figure 1, we plot the aggregate welfare changes for stationary equilibria that differ with respect to the public debt/GDP ratios, relative to the benchmark in which debt amounts to $2 / 3$ of GDP. Figure 1 conveys a clear message: stationary equilibria with lower debt/GDP ratios offer more aggregate welfare, compared to the benchmark economy.

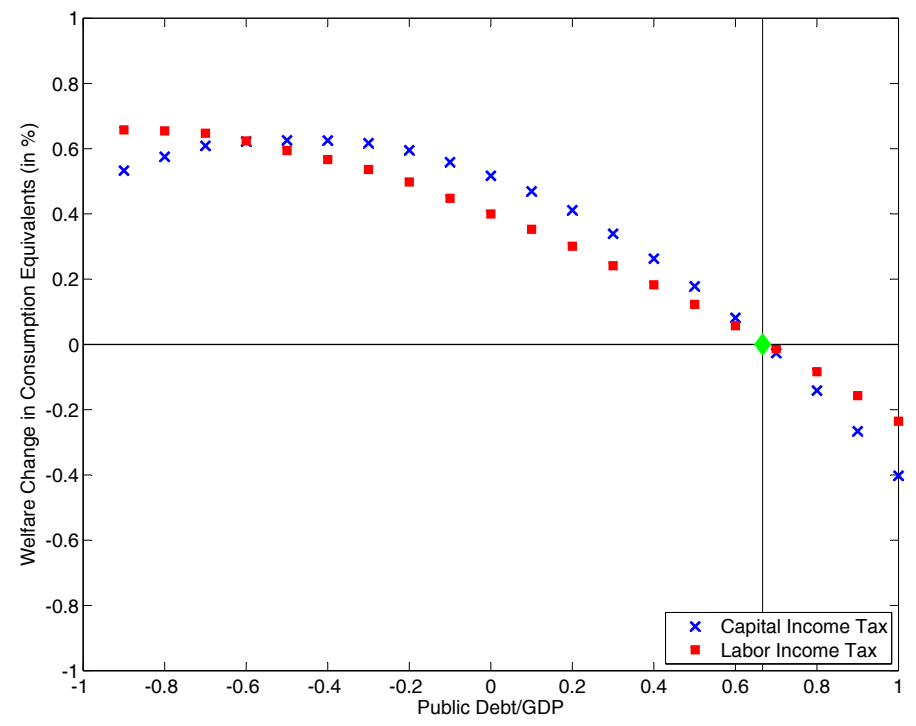

Figure 1: Comparing Welfare Between Different Stationary Equilibria. In this exercise we plot the welfare change in consumption equivalent units implied by our model (on the ordinate) for different stationary equilibria that differ with respect to the public debt/GDP ratio (on the abscissa), relative to the benchmark in which public debt amounts to $2 / 3$ of GDP (green diamond and vertical line). Two cases: (1) the capital income tax is adjusted (blue crosses);(2) the labor income tax is adjusted (red squares).

The long-run welfare effects of government debt result from the interaction between public debt and private capital. It is well-known that government debt crowds out the capital stock if borrowing 
constraints are binding. For our benchmark economy, this effect can be seen in Figure 2, where we depict assets (i.e. aggregate private savings) and the capital stock (private savings minus public debt), relative to GDP.
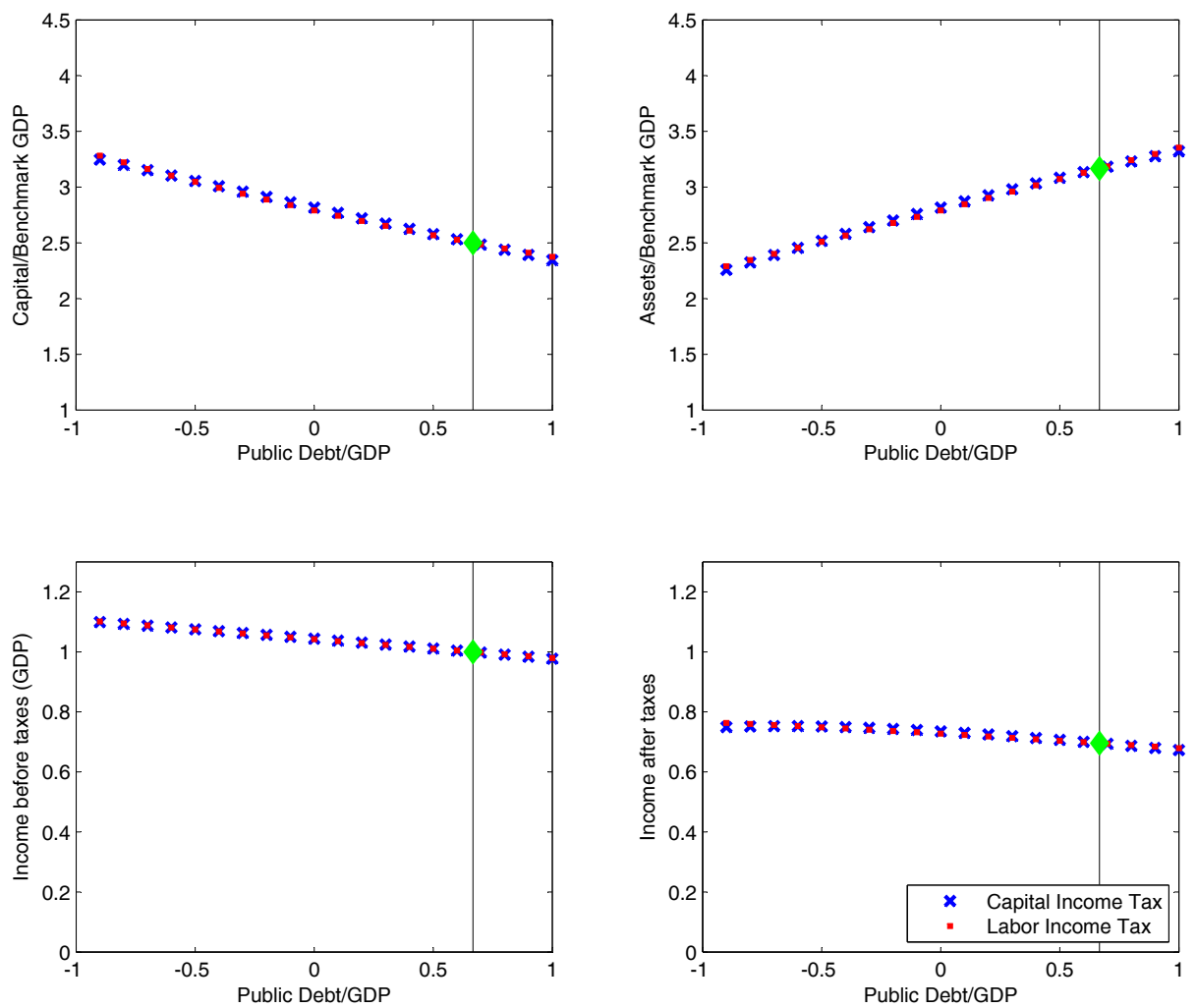

Figure 2: Capital, Assets, Income Before Taxes, Income After Taxes. This figure shows the changes in selected aggregate economic variables (on the ordinate) for different stationary equilibria that differ with respect to the public debt/GDP ratio (on the abscissa). In the benchmark public debt amounts to $2 / 3$ of GDP (green diamond and vertical line). Two cases: (1) capital income tax is adjusted (blue crosses); (2) labor income tax is adjusted (red squares). All variables relative to GDP in the benchmark. 
Higher levels of public debt decrease capital. This means that the increase in assets demanded by households cannot compensate for the increase in asset supplied by the government. The reverse also holds. If government debt is reduced, the capital stock is crowded in. Households do not reduce their asset holdings as much as the government reduces its debt. As a result, the capital stock increases.

If the capital stock in the benchmark economy is below its efficient level, crowding in of capital increases welfare, all other things equal. In a recent paper, Davila et al. (2011) show that in an environment in which markets are incomplete, inequality, in particular the nature of the income risk as well as the composition of income for the consumption-poor, are important determinants for the constrained efficient capital stock. Davila et al. (2011) show that if the earnings process is calibrated as in Castañeda, Díaz-Giménez, and Ríos-Rull (2003) - the method that we employ in this paper - the constraint efficient capital stock is much higher than its laissez-faire level. This finding is in line with our result that government debt reductions increase the private capital stock and raise welfare.

There are three channels, through which government debt reductions affect welfare in the long-run. which we describe each in greater detail in the following. ${ }^{13}$

Level effect: Since lower levels of government debt lead to more private capital, they are associated with more production (see the lower panel in Figure 2) and thus more consumption, all other things equal.

Insurance effect: Figure 3 shows the reaction of the interest rate $r$ and the wage rate $w$ if we change the ratio of public debt/GDP. A decrease in debt, relative to GDP, lowers the interest rate and increases the wage rate. This is consistent with our previous result that an increase in public debt crowds out private assets.

All other things equal, a fall in the interest rate and an increase in the wage rate increases uncertainty in total income. This is because the weight of the uncertain income component, namely labor income is increased relative to capital income, which is certain in our economy. As a result, uncertainty about consumption is amplified as well, and households experience an ex-ante welfare loss.

Income composition effect: A reduction in government debt/GDP implies that asset income falls $r A$, while labor income $w L$ increases. ${ }^{14}$ As a consequence, asset owners experience, on average, a loss in their income if there is more government debt, while those households who primarily depend on labor income experience a gain. We call this the income composition effect. It is important to notice that the income composition effect would also exist if markets were complete and if idiosyncratic shocks were fully insurable. This distinguishes the income composition effect from the uncertainty channel that was previously outlined. In our environment, in which markets are incomplete, the impact of the income composition effect on aggregate welfare is even larger. This is because in our model, wealth is primarily held in order to self-insure against uninsurable income fluctuations. Households who own little wealth,

\footnotetext{
${ }^{13}$ We adopt the labels of Flodén (2001), who distinguishes a "level" effect, an "uncertainty" effect and an "inequality" effect. By re-labeling the inequality effect into "income composition effect", we would like to stress the origin of inequality in the model, namely the fact the composition of income between households differs.

${ }^{14}$ As a consequence of the Cobb-Douglas production technology, the share of labor income in total output is constant. The same is true for capital income. Notice that income from assets is the sum of lending to the government and to private households as well as capital income. Depending on the degree of crowding in/out, the share of asset income, relative to total output, can change.
} 

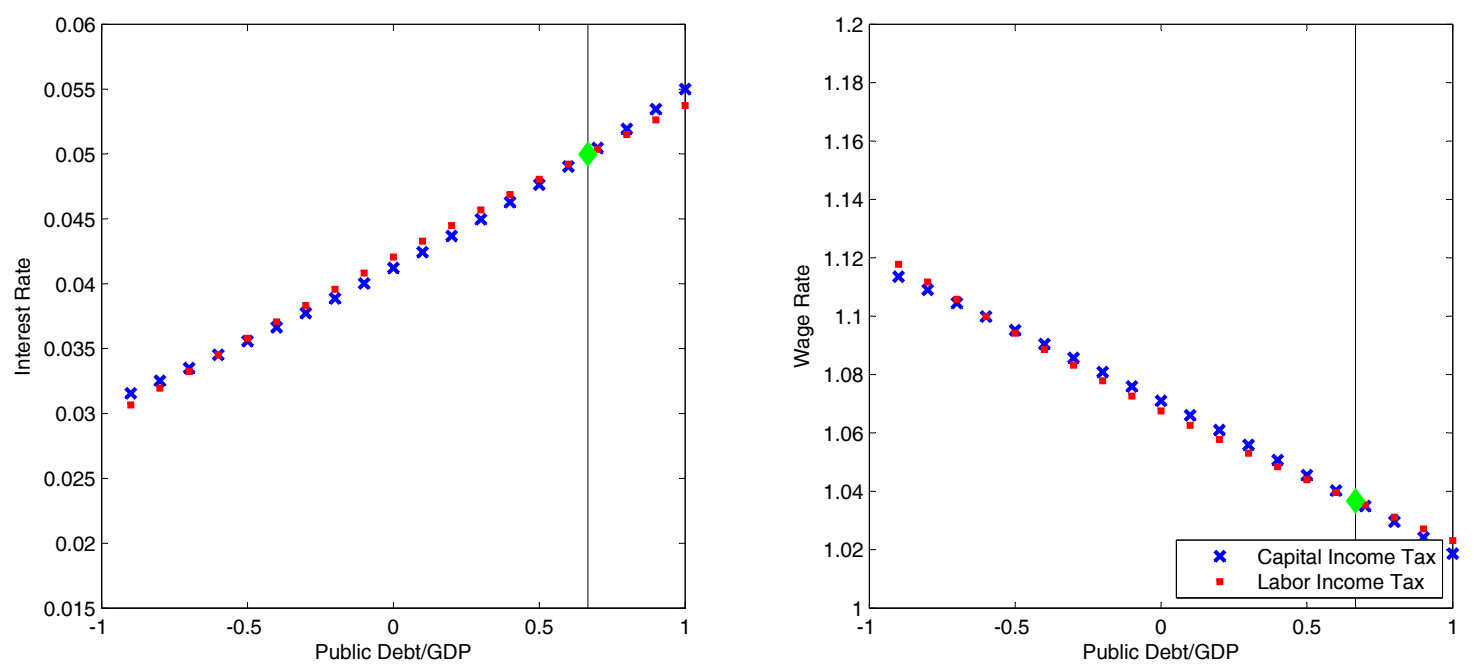

Figure 3: Interest Rate and Wage Rate. This figure shows the changes in equilibrium prices for capital and labor (on the ordinate) for different stationary equilibria that differ with respect to the public debt/GDP ratio (on the abscissa). In the benchmark public debt amounts to $2 / 3$ of GDP (green diamond and vertical line). Two cases: (1) capital income tax is adjusted (blue crosses); (2) labor income tax is adjusted (red squares).

and thus depend heavily on their labor income, are those that have been hit by a sequence of bad shocks. These households are also consumption-poor and thus matter more in the Utiliterian welfare criterion, given the concavity of the utility function.

In sum, a reduction in government debt affects aggregate welfare in the long-run via a level effect, an uncertainty channel and through the composition of individual income. The level effect and the income composition effect imply that lower levels of public debt increase aggregate welfare, whereas higher levels of public debt increase welfare according to the uncertainty effect. The relative strength of each channel depends on the degree of wealth and income inequality in the economy. This highlights the importance of matching the observable degree of wealth and income inequality for computing the welfare-maximizing level of government debt.

Sources of crowding in: borrowing constraint vs. distortionary taxation. As the previous analysis has shown, the long-run welfare effects of government debt reductions depend on the extent to which capital is crowded in. Crowding in can be the result of binding borrowing constraints or of distortionary taxation. It turns out that the borrowing constraints are very important, which is a consequence of the high degree of inequality implied by our model. The sensitivity of the aggregate capital stock with respect to changes in the debt/GDP ratio thus depends on the number of borrowing constrained households, which in turn is closely linked to the wealth distribution implied by the model. In the Appendix, we present an additional experiment that highlights this point.

Finally, we would like to point out that our results differ from the seminal paper of Aiyagari and McGrattan (1998), who find that reducing government debt with respect to its long run average of 0.66 percent of GDP will reduce welfare. The differences between us and Aiyagari and McGrattan (1998) are mainly driven by the fact that our income process implies more wealth and earnings inequality than the 
AR(1) process utilized by Aiyagari and McGrattan (1998). As this section has made clear, inequality is crucial in order to understand the welfare consequences of changes in government debt.

\subsection{Welfare of Different Wealth-Groups: Poor, Middle Class, Rich}

In this subsection, we show that the aggregate welfare effect that we documented before is highly unequally distributed among wealth groups. We analyze three groups of households that are defined as follows:

1. Poor: Households with zero or negative assets.

2. Rich: Group of households who together own 70 percent of total assets.

3. Middle class: Households who do not belong to either of the previous categories.

The logic behind these definitions is as follows. According to our definition, the poor do not receive asset income and are thus only affected by changes in the after-tax wage rate. The rich instead care primarily about the after-tax interest rate. Finally, the middle class is affected by both changes in the after-tax wage rate and in the after-tax interest rate. ${ }^{15}$

In Figure 4, we plot the share of population belonging to the respective groups. In the benchmark steady-state with debt/GDP of 66 percent, around 20 percent of all households are poor according to our definition. Around 2 percent are rich and the rest belongs to the middle class.

The relative group-sizes are not invariant to changes in the debt/GDP ratio, as the first row of Figure 4 makes apparent. The lower debt/GDP, the bigger the fraction of households that are poor. Intuitively, lower interest rates that are associated with lower debt/GDP ratios discourage saving. ${ }^{16}$

The group-specific welfare functions are shown in the second row of Figure 4. The between-group differences are enormous. In particular, the welfare function of the rich is almost exactly the mirror image of the welfare function of the poor. This again highlights the importance of inequality for assessing the welfare effects of changes in government debt. In the following subsection, we move beyond the mere comparison of stationary equilibrium debt/GDP ratios by incorporating the transition into our results.

\subsection{Welfare Over the Transition Path}

We now incorporate the transition between two stationary equilibria into our analysis. In this subsection, we assume that a benevolent government wants to reduce the government debt/GDP ratio. How should the government proceed, if it can only adjust either the capital income tax or the labor income tax? This question is relevant and interesting for at least two reasons. First it is motivated by our long-run analysis above, where we documented that reductions in government debt lead to large welfare gains in long-run. Given this, it is natural to ask whether these long-run gains are offset by losses in the shortrun. Second, the question of how to reduce government debt is also a topical one. Many countries in the world have experienced in increase in their debt/GDP ratios in the aftermath of the financial crisis. In the US, various policies have been proposed to stabilize debt/GDP ratios, see Chen and Imrohoroglu

\footnotetext{
${ }^{15}$ We keep the definition constant in all of the following experiments.

${ }^{16}$ Reducing government debt thus increases wealth inequality (but reduces consumption inequality) in the long run, a result that was already emphasized by Flodén (2001).
} 

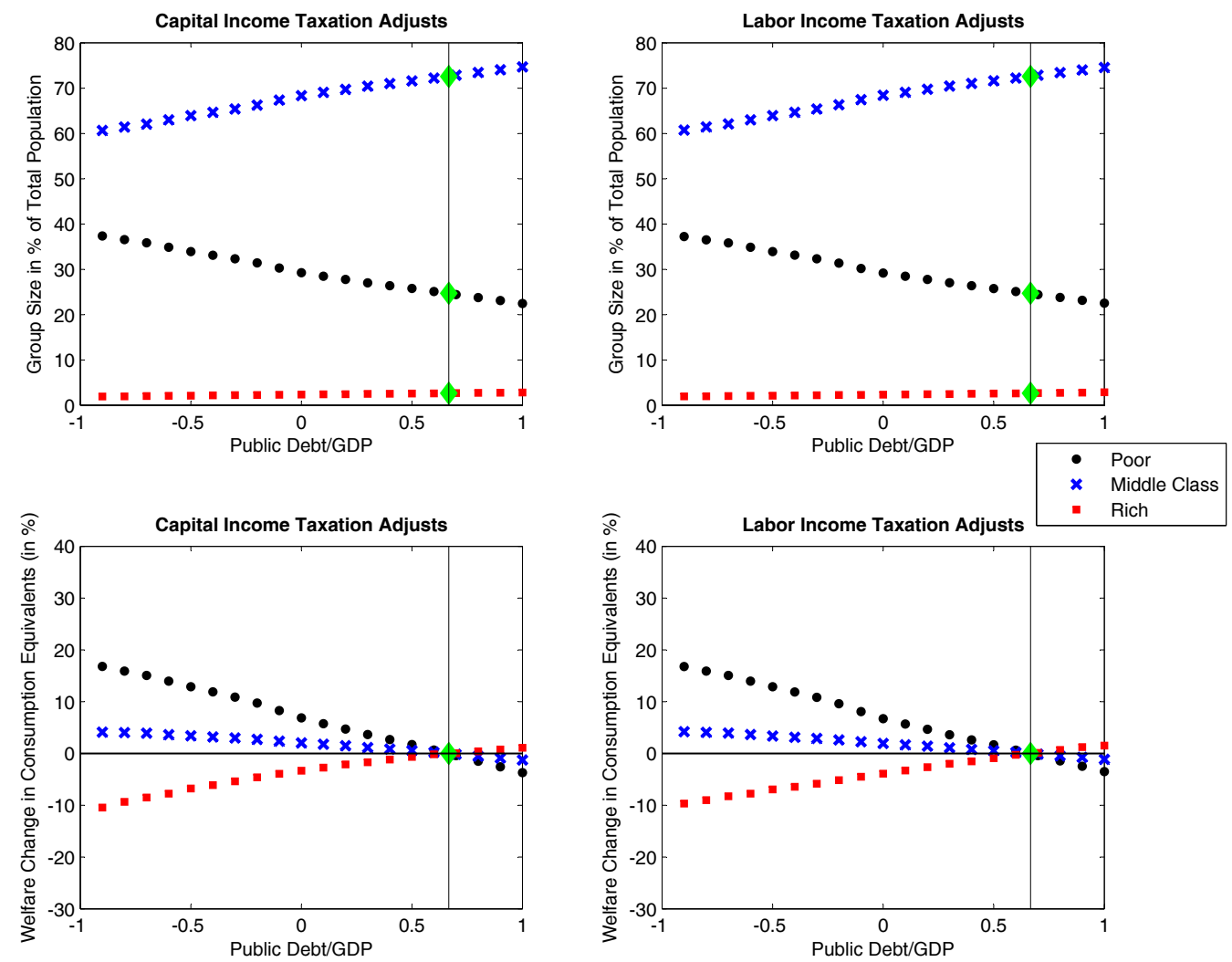

Figure 4: Group Size and Welfare Change of Wealth Groups. This figure shows the changes in group size and welfare of a group (on the ordinate) for different stationary equilibria that differ with respect to the public debt/GDP ratio (on the abscissa). In the benchmark public debt amounts to $2 / 3$ of GDP (green diamond and vertical line). Three groups: (1) the poor have no assets or are in debt (black circles), (2) the rich own $70 \%$ of assets as a group (red squares), (3) the middle class is the rest of the households that are neither rich nor poor (blue crosses). Two cases: (1) capital income tax is adjusted (left panel) and (2) labor income tax is adjusted (right panel).

(2012). Most of these proposed policies also involve tax increases, which is the focus of our paper. We do not consider the welfare effects of spending cuts. ${ }^{17}$ Provided that the calibration is adapted, the method presented in this paper could also be used to evaluate the welfare effect of debt reduction policies in other countries.

Preview of our results. For most of the policies that we consider, the total welfare effect of a debt reduction is negative. However, some policies do better than others. And some would even find the approval of the majority of the population. Under the conditions that capital income taxes are used to finance the debt reduction, that the tax burden is stretched over a sufficiently long time horizon, and that the tax burden is front-loaded, meaning that taxes are high in the beginning and phase out slowly over time, a reduction in debt would win a majority vote. ${ }^{18}$ We also show that front-loading is

\footnotetext{
${ }^{17}$ Since government purchases do not affect the marginal utility of households nor the productivity of firms in our model, the consequences of spending cuts are trivial.

${ }^{18}$ We also study the extreme case of front-loading, which is an unanticipated one period increase in capital income taxation. This policy would not only win a majority vote, but is on top of that also welfare improving.
} 
not a good strategy if labor income is taxed. In general, welfare losses are substantially higher if the reduction in debt is financed with the help of labor income taxation. In sum, our results show that the welfare losses over the transition are particularly large among poor households that depend on labor income. Interestingly, this is the same group that profits from lower debt/GDP ratios in the long-run. Motivated by this observation, we analyze whether making the tax system slightly more redistributive when financing debt reductions can compensate for the welfare losses that poor households suffer over the transition. Indeed, we find that if this policy is chosen, reducing government debt is beneficial for social welfare, not only in a stationary equilibrium, but also during the transition to stationary equilibrium with a lower debt/GDP ratio. Consequently, this policy would be approved by a majority of the population.

Our experiments. In most of our experiments, we reduce government debt by either raising the proportional tax on labor income or on capital income. In some experiments, in which we make the tax code more redistributive, we increase both the proportional tax and the transfer $t r$. We assume that the government adjusts only one of the two tax rates along the transition towards the new stationary equilibrium. The tax increment depends on the target debt/GDP ratio as well as on the time span during which government debt is reduced. There are three scenarios: 'front-loaded', where debt/GDP is reduced faster in the beginning and slowlier towards the end; 'linear', where debt/GDP is reduced linearly over time; 'back-loaded', where debt/GDP is reduced more slowly in the beginning and faster towards the end. In order to highlight the role of the time horizon, we compare the result of two different experiments (15 and 25 years). For capital income taxation, we also discuss the case of a one-time tax increase in the initial period. This policy does not directly generate distortions and is thus treated as a special case.

Using a small debt reduction as an example, Figure 5 shows the time path of public debt for the three scenarios (front-loading, linear, back-loading) if the tax on capital income is adjusted. The second column of Figure 5 depicts the three scenarios for labor income taxation.

In the second row of Figure 5, we plot the tax paths that generate the debt paths. The tax path mirrors the debt path. If debt declines quickly, then taxes must be high in the beginning. The opposite is true if debt is declining only slowly in the beginning, but faster towards the end.

Independently of our assumed scenario, we compute the transition as follows. After public debt has reached its target value, we keep it constant and the economy starts converging towards its new stationary equilibrium, in which tax rates take the values that we presented in the previous subsection. Figure 6 shows the resulting total welfare change from debt reduction experiments where different debt/GDP ratios are targeted (for time horizon 15 and 25 and the three scenarios discussed above).

We now discuss several important features of our results in greater detail.

Labor income vs. capital income taxation Reducing government debt leads to a welfare loss with respect to the benchmark stationary equilibrium. This result is independent of whether the reduction in debt is financed by increasing capital income taxation or by raising labor income taxation.

Interestingly, welfare losses are smaller if debt is reduced by raising capital income taxation. This is because capital income taxes directly affect only those households who own assets. Since wealth is very concentrated in our calibration, a considerable share of the population in our benchmark calibration 

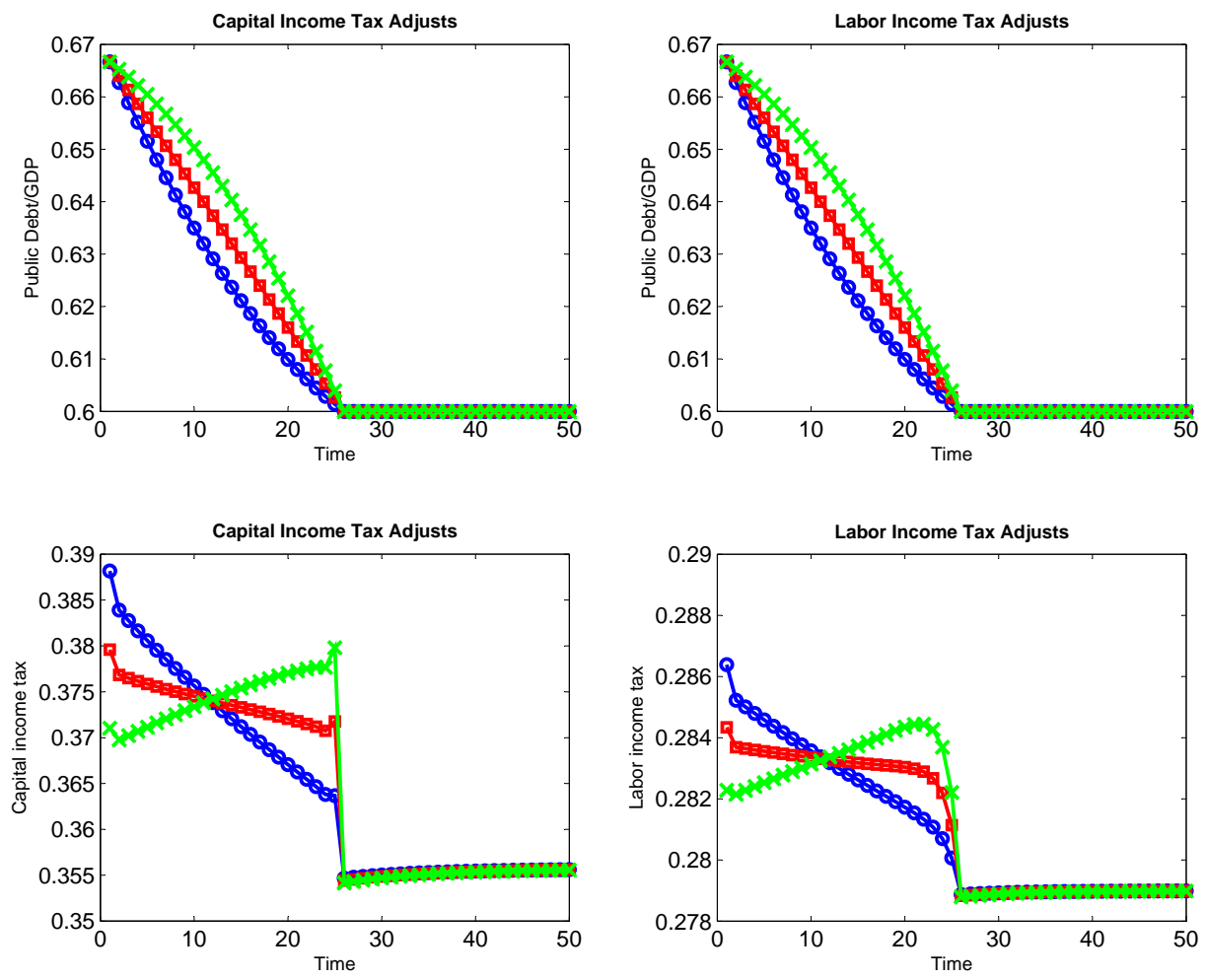

Figure 5: Example of Debt and Tax Path. This figure shows the shape of the debt/GDP (first row) and tax path (second row) over the transition where the government reduces the public debt/GDP ratio from an initial stationary equilibrium value of $2 / 3$ to a new stationary equilibrium value of 0.6 . As an example, we focus on the case where the debt/GDP ratio is reduced in 25 periods. Two cases: capital income tax adjusted (first column); labor income tax adjusted (second column). Three scenarios: front-loaded (blue line with circles), linear (red line with squares) and back-loaded (green line with crosses).

owns no assets or is even indebted. Because these households receive only income from labor, they are not directly affected by higher capital taxes. Moreover, since wealth-poor households are also consumption-poor, their well-being matters more in the Utilitarian welfare criterion. Consequently, the welfare losses from increasing capital income taxes are smaller than the respective welfare losses that result from a similar increase in labor income taxes.

Slow vs. fast reduction of government debt. A key element of any debt reduction plan is the timing. Increasing the number of periods lowers the additional tax burden per period, all other things equal. This is particularly relevant if debt is reduced with the help of labor income taxation. In this case, the welfare costs associated with a debt reduction are lower, the longer the time span during which the debt reduction takes place (see Figure 6). This is intuitive. A longer time horizon implies a lower tax burden and thus also less distortions in each period.

If we consider a debt reduction that is financed by an increase in capital income taxation, the effect of extending the number of periods is ambiguous. If taxes are front-loaded, debt should be decreased as fast as possible. Instead, if taxes are back-loaded, it is better to stretch out the debt reduction over a longer time horizon. The reason is that the combination of front-loading and capital income taxation already minimizes distortions, a finding which is also important if we separate the effects of front-loading 

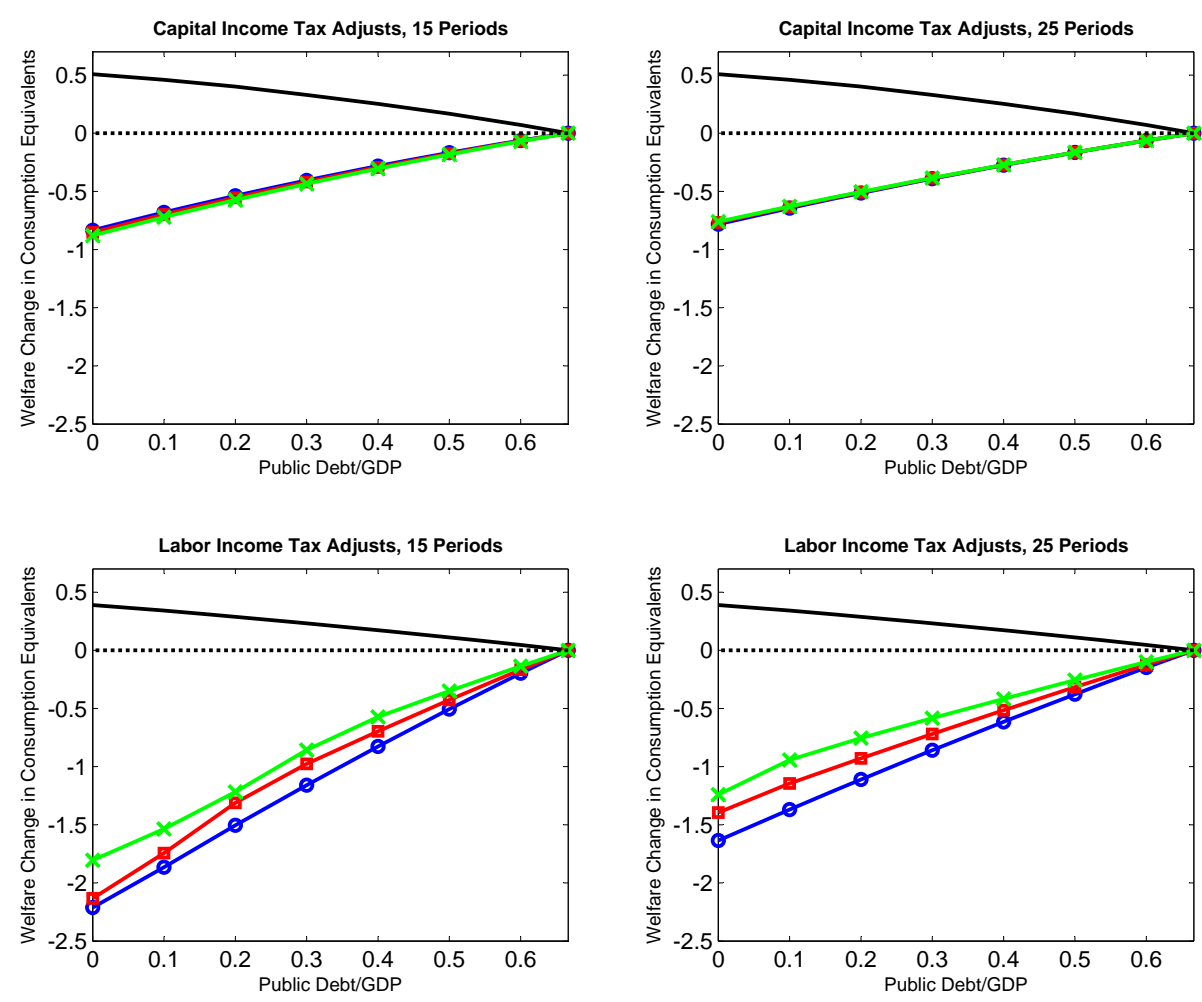

Figure 6: Welfare Including the Transition. In this exercise we plot the welfare change in consumption equivalent units due to a specific debt-reduction experiment (on the ordinate), where public debt/GDP ratio is reduced until a certain target level is reached (on the abscissa), relative to the initial benchmark. Four possible kinds of experiments: adjustment in either capital (first row) or labor (second row) tax rate and duration of policy is either 15 periods (first column) or 25 periods (second column). Three scenarios: (1) front-loaded (blue line with circles), (2) linear (red line with squares), (3) back-loaded (green line with crosses). Also shown: welfare change in new stationary equilibrium alone with transition path excluded (black line).

and back-loading. This is done in the next paragraph.

Front-loading vs. back-loading. Our experiments indicate that if the government aims at reducing its debt quickly with the help of an increase in capital income taxation, it is better to frontload the tax burden (see again Figure 6). If instead labor income taxation is used, it is better to choose back-loading.

The intuition for this finding is as follows. Front-loading the tax burden means that the tax path is high in the beginning and declining over time. If the debt reduction is financed by an increase in capital income taxation, front-loading leads to lower transitional welfare costs because households cannot adjust their assets in the first period. It is important to notice that the government can only profit from front-loading the tax burden if debt is reduced quickly, otherwise it is better to back-load the tax burden.

In contrast, if labor income taxation is used as a means to finance the debt reduction, back-loading is always the preferred option. An increase in labor income taxation distorts mainly the supply of labor. Households can adjust their labor supply freely in any period. Therefore, front-loading does not reduce welfare costs. On the contrary, it hurts all those households who are borrowing constrained. This is 
because the additional tax burden further reduces the consumption of the constrained, which is already suboptimally low. Constrained households prefer a tax path which is increasing over time, such that the negative effects of taxes and currently binding borrowing constraints do not amplify each other.

It is also interesting to notice that the differences between front-loading and back-loading are sizable if the labor income taxation adjusts. However, the impact of the timing is negligible in the case of an adjustment in capital taxation. The reason is that front-loading and back-loading are each associated with offsetting forces on welfare. For example, back-loading is preferred by those who are borrowing constrained. On the other hand, it turns out that back-loading results in a sharp increase in the interest rate. This, in turn, is bad for those who are highly indebted, i.e. those who are close to the borrowing constraint. As a result, the welfare effects of back-loading and front-loading are approximately equal to each other.

The behavior of the interest rate deserves a more detailed explanation. If capital income taxation is adjusted and the tax burden is back-loaded, households foresee an increasing path of capital income taxation. This decreases the incentives to save, leading to higher interest rates.

\section{Special case of one-period policy.}

Before we proceed, we want to shed further light on a special case, which we call one-period policy. Here, we assume that the government needs to implement the new debt level in just one period. Oneperiod policies might be appealing in some cases, as the following results show. Moreover, this special case contains a lot of useful information about the general mechanisms at work. ${ }^{19}$

This case is the one exception to the rule that reducing debt decreases overall welfare once the transition is taken into account and the transfer is kept constant. If the debt reduction is financed by a one-period increase in capital income taxation, total welfare rises compared to the benchmark stationary equilibrium, albeit only slightly. This is because households' assets are fixed for one period. Only after one period, assets can be transformed back into consumption. Therefore, a one-period change in the capital income tax does not directly distort households' behavior. ${ }^{20}$

Interestingly, the welfare gain associated with this policy is very small. For large debt reductions, it is even negative. This may come as a surprise, given that the tax increase used to finance the debt reduction does not directly distort the optimal decisions of households. The reason is that the tax increase which is needed to reduce debt can be very large. For example, if government debt is reduced from 66 percent of GDP to -40 percent, a capital income tax of 689 percent is needed. A capital tax which is larger than 100 percent means that capital owners are expropriated because they need to reduce their assets in order to pay the tax. As a result, the aggregate capital stock shrinks, leading to lower wages and to a reduction of labor income as well. This effect is exacerbated by the fact that the reduction of capital income constitutes a negative wealth shock for asset owners. In response, they

\footnotetext{
${ }^{19}$ Despite of these advantages, we nevertheless decided to treat one-period debt changes as a special case, because the implicit assumption behind all of our policy experiments is that households are surprised by the policy change, which is unlikely to be the case in practice. If the policy is implemented in only one period, households have very little time (or no time at all, if capital income taxation is concerned).

${ }^{20}$ For this reason, the literature that studies optimal taxation typically restricts $\tau_{k}^{0}$ to be smaller than one. See Greulich and Marcet (2008). Otherwise, the optimal tax problem becomes meaningless. We do not impose this restrictions. $\tau_{k}>1$ can be interpreted as a wealth tax. The recent past has seen many incidences where a tax on wealth was implemented on surprise in order to reduce government debt, e.g. the 'patrimoniale' in Italy at the beginning of the 1990s.
} 


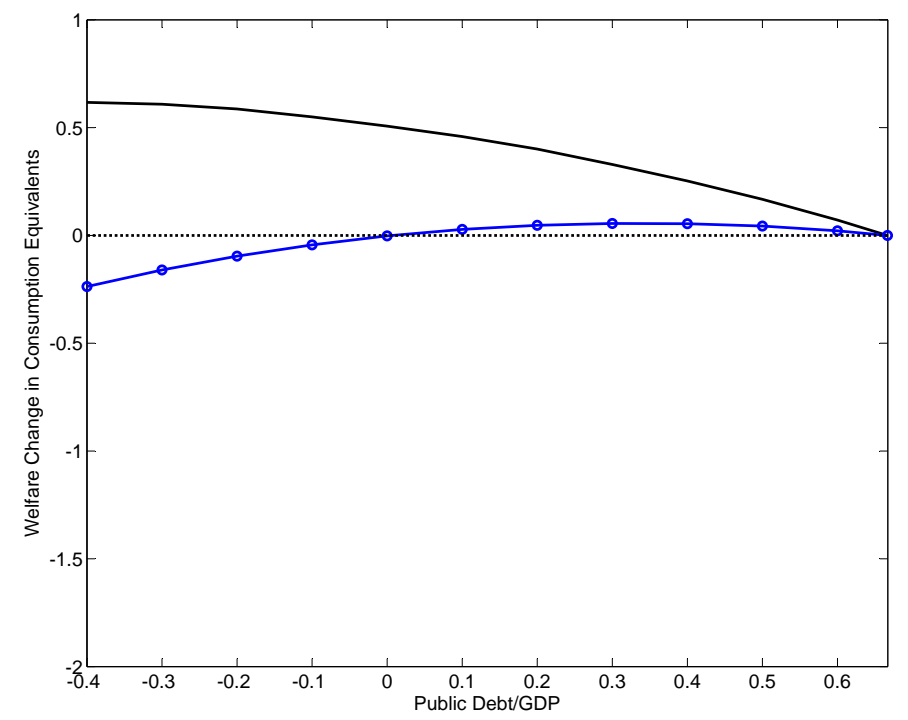

Figure 7: Welfare Change for the 1-Period Policy. In this exercise we plot the welfare change in consumption equivalent units (on the ordinate) when economies transits to new stationary equilibria that differ with respect to the public debt/GDP ratio (on the abscissa), relative to the initial benchmark equilibrium in which public debt amounts to $2 / 3$ of GDP. While reducing government debt to equalize the government budget a tax rate has to be adapted. We focus on the case where the capital tax is raised for only one period. Furthermore, we also show the welfare change with respect to the new stationary equilibrium, when the transition path is excluded (black line).

increase their labor income, which puts even more pressure on wages. This severely affects the income of the poor.

Therefore, the income of the wealth-poor falls in the first period of the transition. From the second period onwards, the poor experience an income gain with respect to the benchmark equilibrium. This gain stems from the fact that the capital stock is converging to its new stationary equilibrium value, which is higher than in the initial stationary equilibrium. Therefore, wages are converging to a higher value as well. Consequently, the welfare of households over the transition is higher than in the initial equilibrium, but lower than in the new stationary equilibrium, which is characterized by a lower debt/GDP ratio. Recall from our long-run analysis above that within the range of debt reductions that we consider here, labor income and thus the welfare of the wealth-poor is unambiguously higher for lower debt/GDP ratios.

This welfare loss occurring over the transition is exacerbated by the presence of borrowing constraints. Without borrowing constraints, poor households could borrow against their future income to smooth out their consumption over time. Thus the loss the poor face over the transition is larger the higher the debt reduction. That is, the more the capital tax rate is increased in the first period, the larger the negative impact on the capital stock and on the wage rate in the first period. Since borrowing is not permitted, this depresses the welfare of the poor over the transition even further.

Figure 9 shows this case. In this Figure, we plot the welfare of different wealth groups for various debt/GDP levels. We analyze three groups: (1) the poor have no assets or are in debt (first subfigure), (2) the rich own $70 \%$ of assets as a group (second subfigure), (3) the middle class is the rest of the households that are neither rich nor poor (third subfigure). The lower the debt/GDP level, the larger 

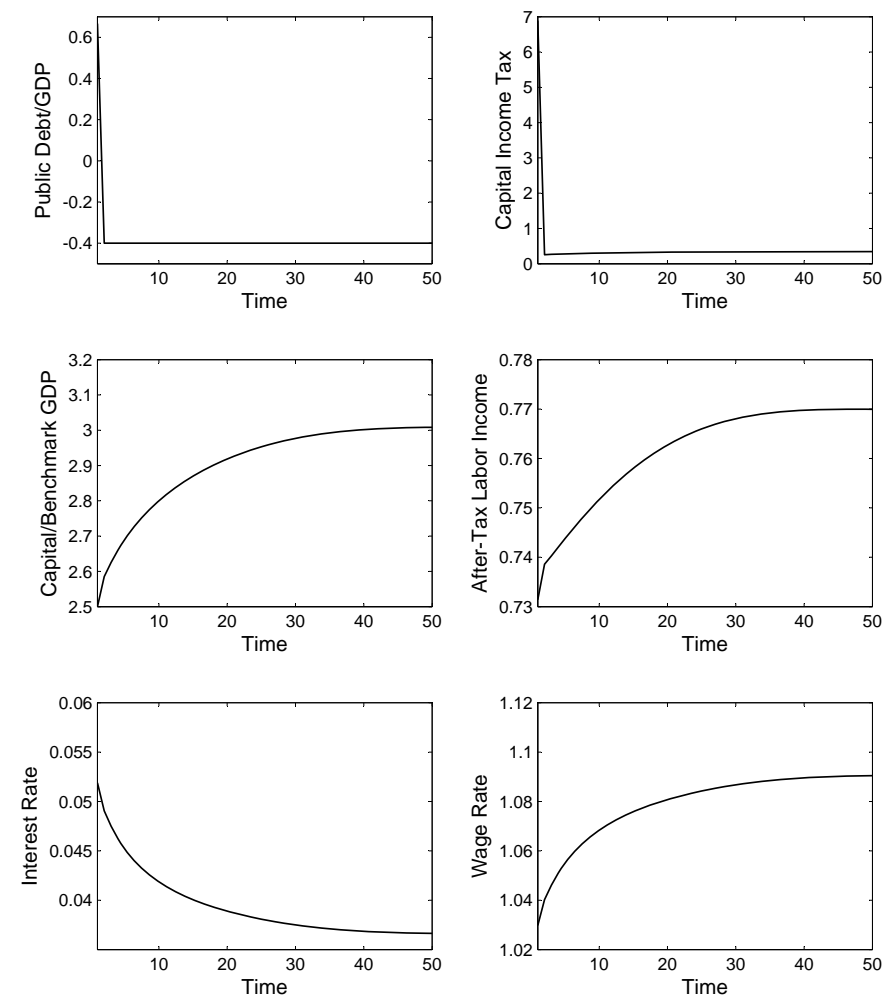

Figure 8: Path of Variables for the 1-Period Policy. In this exercise we plot the transition path of some chosen variables (on the ordinate) over the transition (time axis as abscissa), when reducing public debt/GDP from $2 / 3$ to -0.4 in one period by adjusting the capital income tax. Note that capital is relative to GDP in the benchmark and after-tax labor income is relative to labor income income in the benchmark to be consistent with previous figures.

the discrepancy between the welfare of the wealth-poor over the transition and the welfare in the new stationary equilibrium. Obviously, households who actually own assets face even larger welfare losses over the transition.

In sum, reducing government debt with the help of a one-period capital tax increase may lead to overall welfare gains if the amount by which debt is reduced is fairly small. Otherwise, a very high tax is needed which expropriates asset owners, reduces the total capital stock and thus also total output and the income of the wealth-poor. Because borrowing is not permitted, this means that welfare of the poor increases less relative to the long run and thus also aggregate welfare increases less.

Majority voting vs. Utilitarian welfare criterion. We now analyze which of the debt reduction policies are politically feasible. A debt reduction policy is politically feasible if it is supported by a majority of households. Analyzing the political support of debt reduction policies is a topical question, given that many developing countries will have to implement debt reduction plans in the near future.

We find that many policies lowering public debt would be favored by a majority of households. This is perhaps surprising, given that our previous analysis has shown that almost all policies reduce aggregate welfare, measured by the Utilitarian welfare criterion.

In Figure 10, we plot the political support for various debt reduction policies. As before, we assume that the economy is in the benchmark stationary equilibrium where debt/GDP amounts to 66 percent. 

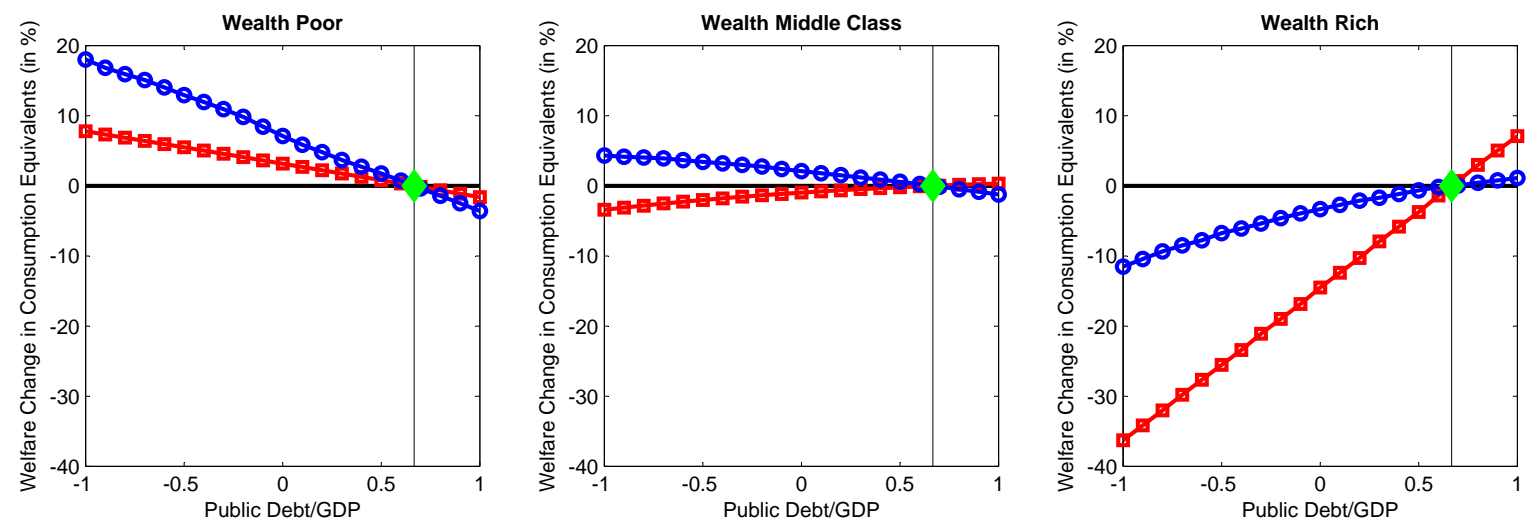

Figure 9: Welfare Change for Different Wealth Groups under the 1-Period Policy. This figure shows the changes in welfare of a group (on the ordinate) for different public debt/GDP ratios (on the abscissa). In the benchmark public debt amounts to $2 / 3$ of GDP (green diamond and vertical line). Three groups: (1) wealth poor (first subfigure), (2) wealth middle class (second subfigure), (3) wealth rich (third subfigure). Both are shown: Welfare change excluding t (blue line with circles) and including (red line with squares) the transition path.

We distinguish debt reduction policies with respect to the targeted debt/GDP ratio and whether the tax burden is front-loaded, back-loaded or linear. ${ }^{21}$ We only present results for policies that involve an adjustment of capital income tax. ${ }^{22}$

A vast majority of households would support a policy that involves only an one-period increase in capital income taxation. Support is decreasing, the larger the debt reduction. However, support is still sufficient to implement a direct jump to the long-run optimum of -0.4 .

This result hinges on the fact that the tax increase is unexpected. This assumption is certainly not very realistic. However, it is not necessary to surprise asset owners to ensure political support. For example, if the tax increase is distributed over two periods, it is still possible to sustain the long-run welfare-maximizing debt level. Even if the tax increase is distributed over 15 periods, one can get very close to the long-run optimum if the tax burden is front-loaded.

Interestingly, households favor front-loading over back-loading, even if the tax increase is spread over many periods. This is surprising, given that back-loading is beneficial for borrowing constrained households. Recall that aggregate welfare is slightly higher for back-loading policies, if we consider a policy horizon of 25 periods. The reason is that the situation for poor households worsens if the tax burden is back-loaded. This is because interest rates are higher and wage rates are lower if the time path of capital income taxes is increasing over time. This in turn stems from the fact that households save less if they foresee higher capital income taxes in the future. High interest rates and low wage rates, in

\footnotetext{
${ }^{21}$ The fraction of households that is in favor of a specific policy reform is computed as $\int I\left(W_{0 \mid \text { reform }}(a, \epsilon)-\right.$ $\left.W_{0 \mid \text { benchmark }}(a, \epsilon)>0\right) d \theta_{0}(a, \epsilon)$, where $I($.$) is an indicator function which is 1$ whenever the statement in brackets is true and zero otherwise, $W_{0 \mid \text { reform }}(a, \epsilon)$ is the value function of an agent with assets $a$ and productivity state $\epsilon$ in period 0 given the reform will be implemented, $W_{0 \mid \text { benchmark }}(a, \epsilon)$ is the value function of an agent with assets $a$ and productivity state $\epsilon$ in period 0 given nothing will happen (the benchmark), $\theta_{0}(a, \epsilon)$ denotes the measure of agents for each asset and productivity state in period 0.

${ }^{22}$ Debt reductions which are financed by an increase in labor income taxation are never politically feasible. The results can be obtained from the authors upon request.
} 

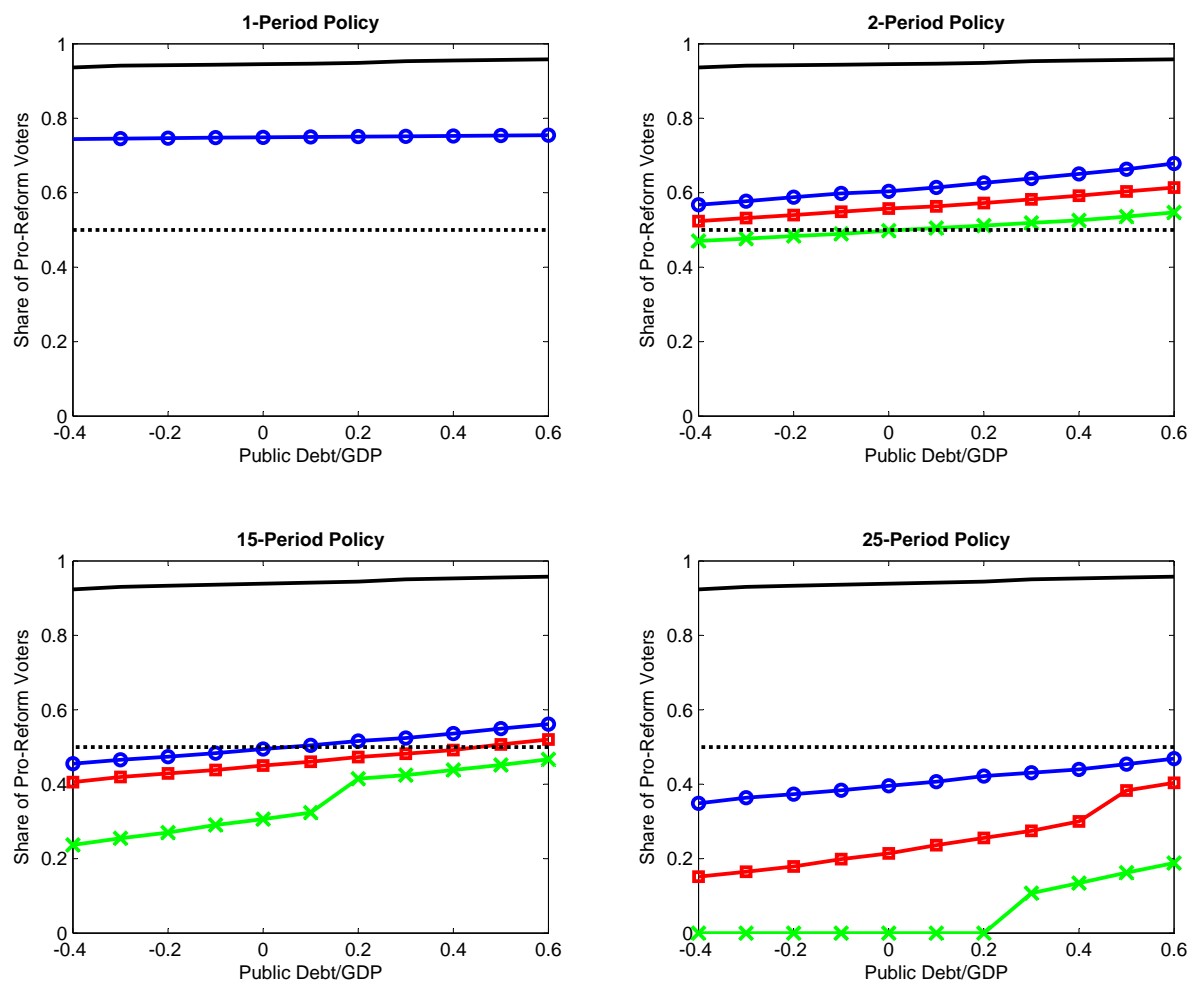

Figure 10: Welfare According to Majority Voting Criterion. In this exercise we plot the percentage of the population that would profit from a reform implied by our model (on the ordinate) where a reform means transiting to a different stationary equilibrium with respect to the public debt/GDP ratio (on the abscissa). Four different time horizons: 1-period policy (first panel in first row), 2-period policy (second panel in first row), 15-period policy (first panel in second row), 25-period policy (second panel in second row). Three different scenarios: (1) front-loaded (blue line with circles), (2) linear (red line with squares), (3) back-loaded (green line with crosses). Also shown: number of pro-reform voters with respect to the new stationary equilibrium, when the transition path is excluded (black line).

turn, hurt those households who are highly indebted and draw low income shocks. Since a substantial fraction of households belongs to this group, back-loading receives little support in our experiments. ${ }^{23}$

In sum, our results show that taxing income from capital is key in order to maximize support for a policy that aims at lowering public debt/GDP. Our experiments suggest that government debt should be reduced as fast as possible. The tax burden should be front-loaded. Thus, the policies that are designed to maximize support can be quite different from those that aim at maximizing social welfare.

A more redistributive tax code. Our previous analysis has shown that debt reductions lead to transitional welfare losses among poor households. We now analyze whether it is possible to design the reduction of government debt such that the poor are compensated for their welfare loss. In order to do so, we analyze the consequences of changing the redistribution that is implied by our tax code. Compared to our previous experiments, this implies that we do not only increase the proportional part of our tax system, but also the lump-sum transfer.

\footnotetext{
${ }^{23}$ Notice that not all households who are close to the borrowing constraint are actually constrained in their borrowing. Those who are close to the constraint and receive a good income shock are more likely to be constrained, given that income shocks are very persistent, implying that these households expect to see their income rising during the near future.
} 

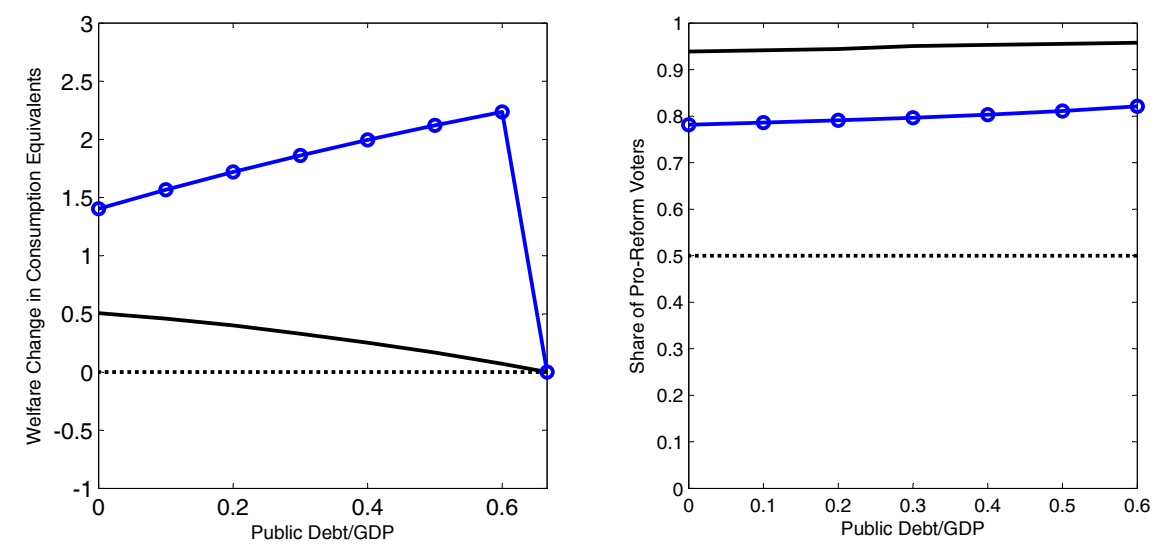

Figure 11: Welfare with Higher Transfer to Poor during Policy Period. Here we plot the welfare change in consumption equivalent units (blue line in the left hand side figure) and the percentage of the population that would profit from a reform implied by our model (blue line right hand side figure) where a reform means transiting to a different stationary equilibrium with respect to the public debt/GDP ratio (on the abscissa). The reduction in government debt is financed by a capital tax and the transfer is increased from roughly 8 percent to 10 percent during the 15 time periods that the tax increase lasts. The black line shows the same welfare measures in the stationary equilibrium only.

In the following, we focus only on capital income taxation. This is because our previous experiments have shown that the welfare loss associated with higher capital income taxation is relatively small. More specifically, in our experiment, we increase the constant component of the tax code by 2 percentage points relative to its benchmark value and adjust the proportional tax rate on capital income, $\tau_{a, t}$, in order to finance a linear decline in government debt during 15 periods.

Figure 11 shows the welfare effects associated with this experiment. Strikingly, we find that there are large welfare gains of debt reductions, even relative to the situation in which the transition to the new stationary equilibrium is ignored. Consequently, this policy would easily gain support of the majority of the population. We thus conclude that even large reductions in government debt can be designed such that they increase social welfare and win the support of the majority of the population.

\section{Conclusion}

In this paper, we analyze the welfare effects of government debt reductions. An important contribution of our project is to compute both the long-run and the short-run welfare consequences of public debt. A key result of our study is that the welfare effects of government debt depend crucially on the degree of wealth and income inequality.

The high degree of wealth and income inequality which can be observed in the US implies that the long-run welfare effects of government debt reductions are large and positive. By lowering debt, the government raises the amount of capital available for production, which in turn increases the equilibrium wage rate and thus benefits those households who depend heavily on labor income.

The short-run welfare costs of reducing government debt are also large. Those who benefit the most from a lower debt/GDP ratio in the long-run, poor households, also suffer the most in the short-run. Borrowing constraints play an important role in our analysis. They govern to what extent households 
are indebted, a crucial determinant of the overall welfare effects. Moreover, the response of households to changes in distorting taxes also depends on their ability to borrow. We assumed that borrowing limits are exogenous, and do not change if public policy changes. In an extension to this project, we relax this assumption and endogenize borrowing constraints by assuming limited commitment (Röhrs and Winter, 2012). Our results suggest that endogenous borrowing constraints reinforce the negative effects of government debt.

Other possible extensions are the introduction of aggregate shock as an additional motive to smooth taxes, along the lines of Barro (1979), Lucas and Stokey (1983), Aiyagari et al. (2002) or Heathcote (2005). Our framework could be readily used to analyze the welfare effects of government debt in other countries, in which wealth and income follow a different distribution. An interesting application is the Euro zone, where currently many proposals to curb government debt are discussed. One of these proposals is to outsource all debt of the individual member countries which exceeds the threshold of so-called Maastricht criteria to a special fund. From this fund, a certain fraction will have to be repaid during a fixed number of predetermined years, by a joint effort of all Euro zone countries. ${ }^{24}$ According to our results, which were obtained for the U.S. economy, the debt repayment scheme should be non-linear.

In this paper, we also implicitly assumed that within families, parents are perfectly altruistic towards their offspring. This does not necessarily need to be the case. We expect that allowing for imperfect altruism would alter both the trade-off between short- and long run welfare effects as well as the relationship between private capital and public debt due to crowding out. If there is no altruism at all, our model would then collapse to a model with overlapping generations, as in e.g. Conesa, Kitao, and Krueger (2009).

Another interesting extension could be to allow for limited commitment. By the choice of our welfare function, we implicitly assumed that the government can commit itself to policies that maximize Utilitarian welfare over an infinite number of periods. If the government cannot commit, a different optimization problem arises as analyzed by Acemoglu, Golosov, and Tsyvinski (2011) in the context of a neoclassical model with Ramsey taxation. Given the tension between short-run and long-run debt policies that our paper reveals, studying the no-commitment case could be potentially fruitful for our understanding of why governments accumulate so much debt. We leave these interesting extensions for future research.

\footnotetext{
${ }^{24}$ This proposal, also labeled "Schuldentilgungsfond", is due to, inter alia, the German Council of Economic Advisors. A time horizon of 20 to 25 years was put forward. See Frankfurter Allgemeine Zeitung, http://www.faz.net/aktuell/wirtschaft/eu-schuldenfonds-harsche-kritik-am-vorschlag-der-wirtschaftsweisen11525389.html, retrieved May 03, 2013.
} 


\section{References}

Ábrahám, Árpád, and Eva Cárceles-Poveda. 2010. "Endogenous Trading Constraints with Incomplete Asset Markets." Journal of Economic Theory 145 (3): 974-1004.

Acemoglu, Daron, Mikhail Golosov, and Aleh Tsyvinski. 2011. "Political economy of Ramsey taxation." Journal of Public Economics 95 (7-8): 467-475.

Aiyagari, S. Rao, Albert Marcet, Thomas J. Sargent, and Juha Seppala. 2002. "Optimal Taxation without State-Contingent Debt." Journal of Political Economy 110 (6): 1220-1254.

Aiyagari, S. Rao, and Ellen R. McGrattan. 1998. "The Optimum Quantity of Debt." Journal of Monetary Economics 42 (3): 447-469.

Aiyagari, S Rao. 1994. "Uninsured Idiosyncratic Risk and Aggregate Saving." The Quarterly Journal of Economics 109 (3): 659-84.

Albanesi, Stefania. 2008. "Comment on: "Markets versus Governments" by Acemoglu, Golosov and Tsyvinski." Journal of Monetary Economics 55 (1): 190-195.

Alesina, Alberto, and Roberto Perotti. 1996. "Political Instability, Income Distribution, and Investment." European Economic Review 40 (6): 1203-1228.

Angeletos, George-Marios, and Vasia Panousi. 2009. "Revisiting the Supply Side Effects of Government Spending." Journal of Monetary Economics 56 (2): 137-153.

Azzimonti, Marina, Eva de Francisco, and Vincenzo Quadrini. 2012. "Financial globalization, inequality, and the raising of public debt." Working papers 12-6, Federal Reserve Bank of Philadelphia.

Bakis, Ozan, Baris Kaymak, and Markus Poschke. 2012. On the Optimality of Progressive Income Redistribution. Mimeo, McGill University.

Barro, Robert J. 1979. "On the Determination of the Public Debt." Journal of Political Economy 87 (5): 940-71 (October).

Castañeda, Ana, Javier Díaz-Giménez, and José-Víctor Ríos-Rull. 2003. "Accounting for the U.S. Earnings and Wealth Inequality." Journal of Political Economy 111 (4): 818-857 (August).

Challe, Edouard, and Xavier Ragot. 2010. "Fiscal Policy in a Tractable Liquidity-Constrained Economy." The Economic Journal 121:273-317.

Chen, Kaiji, and Ayse Imrohoroglu. 2012. Debt and the U.S. Economy. Mimeo, Society for Economic Dynamics in its series 2012 Meeting Papers (No. 229).

Conesa, Juan Carlos, Sagiri Kitao, and Dirk Krueger. 2009. "Taxing Capital? Not a Bad Idea after All!" American Economic Review 99 (1): 25-48 (March).

Cooley, Thomas F., and Edward C. Prescott. 1995. "Economic Growth and Business Cycles." In Frontiers of Buesiness Cycle Research, edited by Thomas F. Cooley. Princeton University Press.

Davila, Julio, Jay H. Hong, Per Krusell, and José-Víctor Ríos-Rull. 2011. Constrained Efficiency in the Neoclassical Growth Model with Uninsurable Idiosyncratic Shocks. Mimeo, Department of Economics, University of Minnesota. 
D'Erasmo, Pablo, and Enrique Mendoza. 2012. Domestic Sovereign Default as Optimal Redistributive Policy. Mimeo, Department of Economics, Georgetown University.

Desbonnet, Audrey, and Thomas Weitzenblum. 2011. "Why do governments end up with debt? Short-run effects matter." Economic Inquiry.

Domeij, David, and Jonathan Heathcote. 2004. "On The Distributional Effects Of Reducing Capital Taxes." International Economic Review 45 (2): 523-554 (05).

Flodén, Martin. 2001. "The Effectiveness of Government Debt and Transfers as Insurance." Journal of Monetary Economics 48 (1): 81-108 (August).

Golosov, Mikhail, and Thomas Sargent. 2012. Taxation, Redistribution, and Debt with Aggregate Shocks. Mimeo, Princeton University.

Gomes, Francisco, Alexander Michaelides, and Valery Polkovnichenko. 2012. Quantifying the Distortionary Fiscal Cost of 'The Bailout'. Mimeo, University of Cyprus.

—. 2013. "Fiscal Policy and Asset Prices with Incomplete Markets." The Review of Financial Studies 26:531-566.

Gottardi, Piero, Atsushi Kajii, and Tomoyuki Nakajima. 2010, 01. "Constrained Inefficiency and Optimal Taxation with Uninsurable Risks." Economics working papers ECO2010/02, European University Institute.

Greulich, Katharina, and Albert Marcet. 2008, February. "Pareto-Improving Optimal Capital and Labor Taxes." Ufae and iae working papers 733.08, Unitat de Fonaments de l'Anàlisi Econòmica (UAB) and Institut d'Anàlisi Econòmica (CSIC).

Heathcote, Jonathan. 2005. "Fiscal Policy with Heterogeneous Agents and Incomplete Markets." Review of Economic Studies 72 (1): 161-188 (01).

Keane, Michael P., and Richard Rogerson. 2011, September. "Reconciling Micro and Macro Labor Supply Elasticities: A Structural Perspective." Nber working papers 17430, National Bureau of Economic Research, Inc.

Krusell, Per, and Anthony Smith. 1998. "Income and Wealth Heterogeneity in the Macroeconomy." Journal of Political Economy 106 (5): 867-896 (October).

Lucas, Robert, and Nancy Stokey. 1983. "Optimal Fiscal and Monetary Policy in an Economy without Capital." Journal of Monetary Economics 12 (1): 53-93.

Ludwig, Alexander, and Dirk Krüger. 2013. "Optimal Progressive Taxation and Education Subsidies in a Model of Endogenous Human Capital Formation." Forthcoming in: AER Papers and Proceedings.

Mendoza, Enrique G., Assaf Razin, and Linda L. Tesar. 1994. "Effective Tax Rates in Macroeconomics: Cross-Country Estimates of Tax Rates on Factor Incomes and Consumption." Journal of Monetary Economics 34 (3): 297-323 (December).

Oh, H., and Ricardo Reis. 2012. "Targeted Transfers and The Fiscal Response to the Great Recession." Journal of Monetary Economics 59:S50-S64.

Ponticelli, Jacopo, and Hans-Joachim Voth. 2011. "Austerity and Anarchy: Budget Cuts and Social Unrest in Europe, 1919-2008." SSRN eLibrary. 
Quadrini, Vincenzo, and José-Víctor Ríos-Rull. 1997. "Understanding the U.S. distribution of wealth." Quarterly Review, no. Spr:22-36.

Reinhart, Carmen M., and Kenneth S. Rogoff. 2009. This Time is Different: Eight Centuries of Financial Folly. Princeton University Press.

Röhrs, Sigrid, and Christoph Winter. 2012. Public vs. Private Debt: The Optimal Provision of Government Debt if Private Borrowing LImits are Endogenous. Mimeo. University of Zurich.

Shin, Yongseok. 2006. Ramsey Meets Bewley: Optimal Government Financing with Incomplete Markets. Mimeo. Unpublished manuscript, Washington University in St. Louis.

Trabandt, Mathias, and Harald Uhlig. 2009, September. "How Far Are We From The Slippery Slope? The Laffer Curve Revisited." Nber working papers 15343, National Bureau of Economic Research, Inc.

Woodford, Michael. 1990. "Public Debt as Private Liquidity." American Economic Review 80 (2): 382-88 (May). 


\section{Appendix}

\section{A: Detrended Formulation of the Households' Maximization Problem}

In our model, there is a balanced growth path along which variables will be growing at the rate of technology growth. To find the stationary equilibrium of the model or to compute the transition from one stationary equilibrium to another it is useful to first detrend variables with respect to this exogenous productivity growth component to obtain a formulation where variables are constant in the balanced growth equilibrium. (This procedure was also used in the earlier literature, for example by Aiyagari and McGrattan, 1998 and Flodén, 2001). Denote a detrended variable by "tilde": $\tilde{x}=\frac{x}{Y}$. The present value of lifetime utility (for a Cobb-Douglas can then be denoted as follows:

$$
U\left(\left\{\tilde{c}_{t}\right\}_{t=1,2, \ldots},\left\{1-l_{t}\right\}_{t=1,2 \ldots}\right)=E_{0} \sum_{t=0}^{\infty} \beta^{t} Y_{t}^{\eta(1-\mu)} u\left(\tilde{c}_{t}, 1-l_{t}\right)
$$

Now using the fact that $Y_{t}=Y_{0}(1+g)^{t}$, where $Y_{0}$ is output in period 0 , we can write:

$$
\begin{aligned}
U\left(\left\{\tilde{c}_{t}\right\}_{t=1,2, \ldots},\left\{1-l_{t}\right\}_{t=1,2 \ldots}\right) & =Y_{0}^{\eta(1-\mu)} E_{0} \sum_{t=0}^{\infty} \beta^{t}(1+g)^{t \eta(1-\mu)} u\left(\tilde{c}_{t}, 1-l_{t}\right) \\
& =Y_{0}^{\eta(1-\mu)} E_{0} \sum_{t=0}^{\infty} \tilde{\beta}^{t} u\left(\tilde{c}_{t}, 1-l_{t}\right)
\end{aligned}
$$

where $\tilde{\beta}=\beta \cdot(1+g)^{\eta(1-\mu)}$.

Similarly, we can find a detrended version of the household budget constraint by dividing it by $Y_{t}$ :

$$
\begin{aligned}
\frac{c_{t}}{Y_{t}}+\frac{Y_{t+1}}{Y_{t}} \frac{a_{t+1}}{Y_{t+1}} & =\frac{\bar{w}_{t}}{Y_{t}} \epsilon l_{t}+\left(1+\bar{r}_{t}\right) \frac{a}{Y_{t}}+t r \\
\tilde{c}_{t}+(1+g) \tilde{a}_{t+1} & =\tilde{\tilde{w}}_{t} \epsilon l_{t}+\left(1+\bar{r}_{t}\right) \tilde{a}_{t}+\tilde{t r}_{t}
\end{aligned}
$$

Also the borrowing constraint can be detrended:

$$
\tilde{a}_{t+1} \geq \underline{\tilde{a}}_{t}
$$

The resulting recursive formulation in detrended variables is given by:

$$
\begin{aligned}
W_{t}(\tilde{a}, \epsilon ; \theta) & =\max _{\tilde{a}, c} Y_{0}^{\eta(1-\mu)} u(\tilde{c}, 1-l)+\tilde{\beta} \sum_{\epsilon^{\prime}} \pi\left(\epsilon^{\prime} \mid \epsilon\right) W_{t+1}\left(\tilde{a}^{\prime}, \epsilon^{\prime} ; \theta^{\prime}\right) \\
\text { s.t. } \tilde{c}+(1+g) \tilde{a}^{\prime} & =\tilde{\tilde{w}} \epsilon l+(1+\bar{r}) \tilde{a}+\tilde{t r} \\
\tilde{a}^{\prime} & \geq \underline{\tilde{a}} \\
\theta^{\prime} & =\Gamma[\theta]
\end{aligned}
$$

\section{B: Definition of the Consumption Equivalent Welfare Change}

A new stationary equilibrium versus the benchmark. The consumption equivalent welfare change for the average household is defined as the percentage change in consumption that the household must incur in the old situation in order to be indifferent between staying in the old situation and being in a 
new stationary equilibrium with different policies for debt and taxes. Let the old stationary equilibrium be denoted by the subscript old and be characterized by a (detrended) debt level $\tilde{b}_{\text {old }}=\frac{B_{\text {old }}}{Y_{\text {old }}}$ and a resulting density $\theta_{\text {old }}$. In our computations this point of comparison will always be the benchmark equilibrium with $\tilde{b}_{\text {old }}=\frac{2}{3}$. Let the new situation be denoted by the subscript new and characterized by the debt level $\tilde{b}_{\text {new }} \neq \tilde{b}_{\text {old }}$ and a resulting density $\theta_{\text {new }}$. Using this notation, the consumption equivalent change for the average household, $x_{\text {old } \rightarrow \text { new }}$, is defined as follows:

$$
\begin{aligned}
& \int W_{\text {old }}\left(\tilde{a}, \epsilon ; x_{\text {old } \rightarrow \text { new }}\right) d \theta_{\text {old }}(\tilde{a}, \epsilon)=\int W_{\text {new }}(\tilde{a}, \epsilon) d \theta_{\text {new }}(\tilde{a}, \epsilon) \\
& \int E_{0} \sum_{t=0}^{\infty} \tilde{\beta}^{t} \frac{\left(\left(c_{\text {old }}(\tilde{a}, \epsilon)\left(1+x_{\text {old } \rightarrow \text { new }}\right)\right)^{\eta}\left(1-l_{\text {old }}(\tilde{a}, \epsilon)\right)^{1-\eta}\right)^{1-\mu}}{1-\mu} d \theta_{\text {old }}(\tilde{a}, \epsilon)= \\
& \int E_{0} \sum_{t=0}^{\infty} \tilde{\beta}^{t} \frac{\left(c_{\text {new }}(\tilde{a}, \epsilon)^{\eta}\left(1-l_{\text {new }}(\tilde{a}, \epsilon)\right)^{1-\eta}\right)^{1-\mu}}{1-\mu} d \theta_{\text {new }}(\tilde{a}, \epsilon)
\end{aligned}
$$

Solving this equation for $x_{\text {old } \rightarrow \text { new }}$ we obtain:

$$
\begin{aligned}
& x_{\text {old } \rightarrow \text { new }}=\left(\frac{\int E_{t=0} \sum_{t=0}^{\infty} \tilde{\beta}^{t} \frac{\left(c_{\text {new }}(\tilde{a}, \epsilon)^{\eta}\left(1-l_{\text {new }}(\tilde{a}, \epsilon)\right)^{1-\eta}\right)^{1-\mu}}{1-\mu} d \theta_{\text {new }}(\tilde{a}, \epsilon)}{\int E_{t=0} \sum_{t=0}^{\infty} \tilde{\beta}^{t} \frac{\left(c_{\text {old }}(\tilde{a}, \epsilon)^{\eta}\left(1-l_{\text {old }}(\tilde{a}, \epsilon)\right)^{1-\eta}\right)^{1-\mu}}{1-\mu} d \theta_{\text {old }}(\tilde{a}, \epsilon)}\right)^{\frac{1}{\eta(1-\mu)}}-1 \\
& =\left(\frac{\int W_{\text {new }}(\tilde{a}, \epsilon) d \theta_{\text {new }}(\tilde{a}, \epsilon)}{\int W_{\text {old }}(\tilde{a}, \epsilon) d \theta_{\text {old }}(\tilde{a}, \epsilon)}\right)^{\frac{1}{\eta(1-\mu)}}-1
\end{aligned}
$$

If $x_{\text {old }} \rightarrow x_{\text {new }}$ is positive, the average household would prefer changing to the new equilibrium, even without being compensated. If instead $x_{\text {old }} \rightarrow x_{\text {new }}$ is negative, compensation in terms of $x_{\text {old }} \rightarrow x_{\text {new }}$ consumption units is required in order to make the household indifferent.

\section{Comparing the transitional path to a new stationary equilibrium and the benchmark.}

When we include the transitional path into our considerations, we compare welfare of the average household in period 0 when a change in policy is announced and when staying at the benchmark. Let the detrended debt level in period 0 be denoted by $\tilde{b}_{0}$ and the density by $\theta_{0}$. We assume that households are surprised by the new policy. Similar to above we will denote the old situation with the subscript old and the new situation with the subscript new. The only difference is that we now use subscripts $t$ (since we are not always in the stationary equilibrium) and the initial debt level $b_{0}$ and density $\theta_{0}$ are the same in both situations. The consumption equivalent welfare change for the average household $x_{\text {old } \rightarrow \text { new }}$ is again defined as the percentage change in consumption in situation old that makes the household indifferent between staying in old and going to new:

$$
\begin{aligned}
& \int W_{\text {old }, t=0}\left(\tilde{a}, \epsilon ; x_{\text {old } \rightarrow \text { new }}\right) d \theta_{0}(\tilde{a}, \epsilon)=\int W_{\text {new }, t=0}(\tilde{a}, \epsilon) d \theta_{0}(\tilde{a}, \epsilon) \\
& \int E_{0} \sum_{t=0}^{\infty} \tilde{\beta}^{t} \frac{\left(\left(c_{\text {old }, t}(\tilde{a}, \epsilon)\left(1+x_{\text {old } \rightarrow \text { new }}\right)\right)^{\eta}\left(1-l_{\text {old }, t}(\tilde{a}, \epsilon)\right)^{1-\eta}\right)^{1-\mu}}{1-\mu} d \theta_{0}(\tilde{a}, \epsilon)= \\
& \int E_{0} \sum_{t=0}^{\infty} \tilde{\beta}^{t} \frac{\left(c_{\text {new }, t}(\tilde{a}, \epsilon)^{\eta}\left(1-l_{\text {new }, t}(\tilde{a}, \epsilon)\right)^{1-\eta}\right)^{1-\mu}}{1-\mu} d \theta_{0}(\tilde{a}, \epsilon)
\end{aligned}
$$


Solving this equation for $x_{\text {old } \rightarrow \text { new }}$ we obtain:

$$
x_{\text {old } \rightarrow \text { new }}=\left(\frac{\int W_{\text {new }, t=0}(\tilde{a}, \epsilon) d \theta_{0}(\tilde{a}, \epsilon)}{\int W_{\text {old }, t=0}(\tilde{a}, \epsilon) d \theta_{0}(\tilde{a}, \epsilon)}\right)^{\frac{1}{\eta(1-\mu)}}-1
$$

\section{C: The Impact of Distortive Taxation}

In this section we want to address the concern that our results about crowding out and welfare for stationary equilibria with different debt/GDP ratios are solely due to the distortiveness of taxation instead of the effect of government debt itself. To do this we analyze the following additional experiment: We fix the labor and the capital tax rate at their benchmark levels. When we adjust the debt/GDP ratio, we modify only the lump sum transfer in order to keep the government's budget balanced.

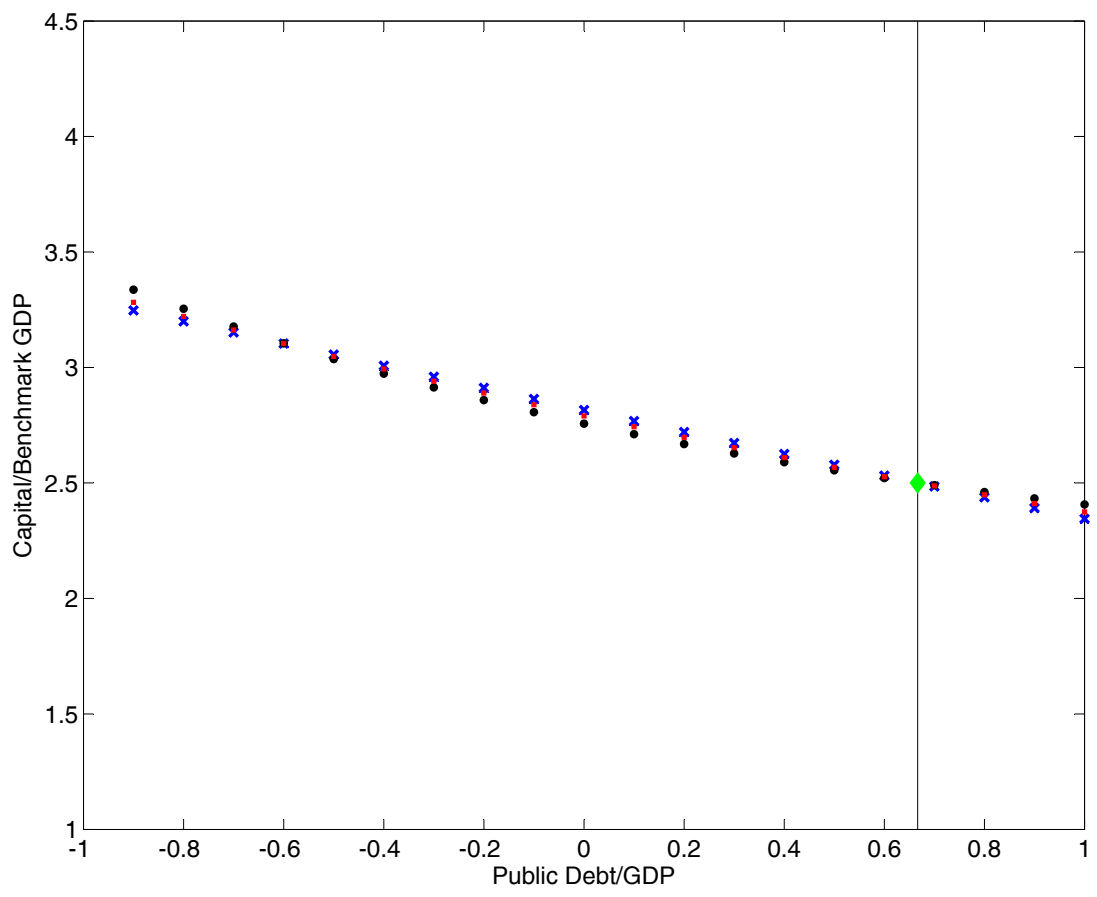

Figure 12: Welfare Analysis and Crowding Out with Lump Sum Tax. In this exercise we plot Capital divided by benchmark GDP (on the ordinate) for different stationary equilibria that differ with respect to the public debt/GDP ratio (on the abscissa), relative to the benchmark in which public debt amounts to $2 / 3$ of GDP (green diamond and vertical line). In the stationary equilibrium to equalize the government budget with a different tax base and different debt/GDP ratio either the capital income tax (blue crosses), the labor income tax (red squares) or the transfer/lump sum component (black circles) has to be adapted.

Figure 12 compares the three possible tax adjustment policies in terms of their crowding out effect. Clearly, the difference between tax policies is not very pronounced. We thus conclude that crowding out is mainly due to the change in the level of government debt and thus only marginally changes for different tax policies. 